Portland State University

PDXScholar

6-1-1972

\title{
The pregnancy counseling group; an analysis of a sample of women served by Planned Parenthood Association, Portland, Oregon
}

Marcia Jean Lapham

Portland State University

Follow this and additional works at: https://pdxscholar.library.pdx.edu/open_access_etds Let us know how access to this document benefits you.

Recommended Citation

Lapham, Marcia Jean, "The pregnancy counseling group; an analysis of a sample of women served by Planned Parenthood Association, Portland, Oregon" (1972). Dissertations and Theses. Paper 788.

https://doi.org/10.15760/etd.788

This Thesis is brought to you for free and open access. It has been accepted for inclusion in Dissertations and Theses by an authorized administrator of PDXScholar. Please contact us if we can make this document more accessible: pdxscholar@pdx.edu. 
THE PREGNANCY COUNSELING GROUP

AN ANALYSIS OF A SAMPLE OF WOMEN SERVED BY

PLANNED PARENTHOOD ASSOCIATION

PORTLAND, OREGON

1971

by

MARCIA JEAN DALIN IAAPHAM

A report submitted in partial fulfillment of the requirements for the degree of

MASTER OF SOCIAL WORK

Portland State University 1972 
TO THE OFFICE OF GRADUATE STUDIES:

The members of the Committee approve the research report of Marcia Jean Dalin Lapham presented June 5, 1972.

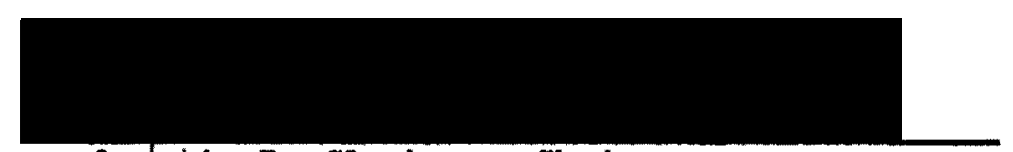

Quentin D. Clarkson, Chairman

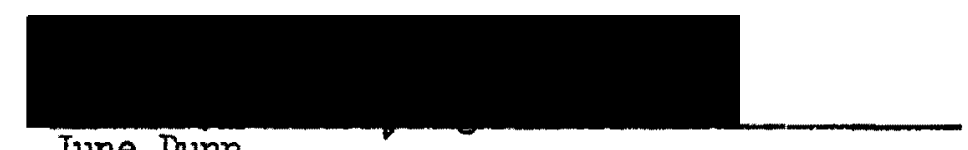

June Iunn

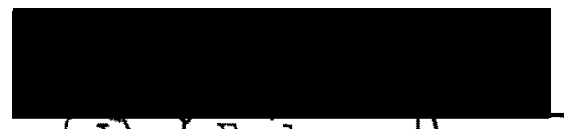

Japet Engle

APPROVED:

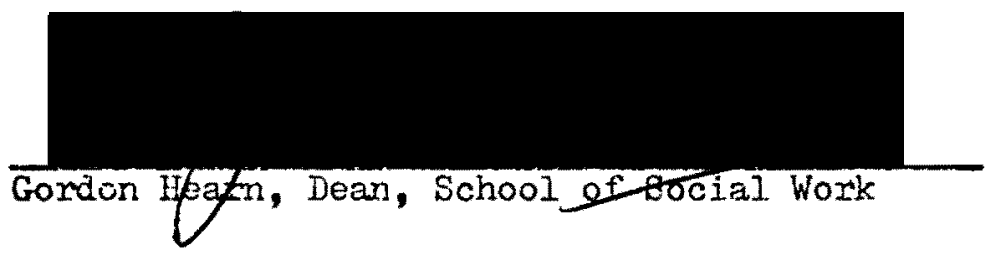

June 5, 1972 


\section{ACKNOWLEIDGMENTS}

I wish to acknowledge and thark the following persons who contributed to this study: Jesalee Fosterling, Bxecutive Director of Planned Parenthood Association with whom the toplc was first discussed; the members of the Planned Parenthood Assoniation Research Committee: Helen Catlin, Fred Hutchinson and Dr. Chadwick Karr who reviewed the original proposal; and the members of the agency staff, both professional and volunteer, who provided information and answered questions, particularly Jeffrey Grass of the record room who shared space and located those records not readily found.

I am especially indebted to Dr. Quentin D. Clarkson and June Ihinn of the Portland State University School of Social Work Paculty and Janet Engle, Clinic Social Worker, Planned Parenthood Association, for the time spent in consultation, suggestions, and review of the manuscript.

I also wish to thank David Lapham for translating the tables into the final inked form and making the adaptations necessary to meet margin requirements. 


\section{LIST OF FIGURkS}

\section{FIGURE}

PAGE

1 Age Distribution Population and Sample ....... 52

2 Sample Distribution by Patient Status ...... 53 
LIST OF TABLES

TABIE

PAGE

I Age Distributions . . . . . . . . . . 54

II Education by Age I . . . . . . . . . . 55

III Education by Age II ............ 56

IV Decision by Race .... . . . . . . . 57

v Source of Support and Living Situation . . . . . 58

VI Reproductive History .............. 59

VII How They Came to the Agency ............ 60

VII Patient Status .............. 61

IX Contraceptive Knowledge and Use by Age . . . . .

A. Total Group ............. 62

B. Younger Patients ............ 63

C. Use at Time of Conception ........ 64

$X$ History of Pill and IUD Use . . . . . . . 65

XI Status by Contraceptive Circumstance . . . . . . 55

XII Gestation by Age .............. 66

XIII Gestation by Reiiable Niethod Failure . . . . . 66

XIV "In Between" Group by Gestation .......... 67

XV "In Between" Group by Decision . . . . . . . 67

XVI Decision by Age .................. 68

XVII Abortion Precent by Age ............ 68 
XVIII Decision Marriage and Baby by Age ......... 68

XIX Decision by Previous Abortion or Release ...... 68

XX Decision by Marriage I ............ 69

XXI Decision by Marriage II ............ 69

XXII Decision by "No Future Children Ever" ....... 69

XXIII Decision by Number of Children with Mother I . . . 70

XXIV Decision by Number of Children with Mother II . . 70

XXV Decision by Contraceptive Failure Reliable Method . . 70

XXVI "Do You Want Future Children?" . . . . . . . . 71

XXVII No Future Children Ever by Number of Children . . 71

XXVIII Referral by Decision . . . . . . . . 72

XXIX Essential Data Omitted by Calendar Quarter .... 73 
TABLE OF CONTENTS

PAGE

ACKNOWTHDCMENTS

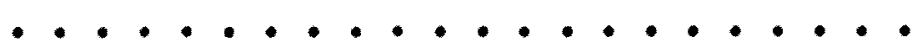

CHAPTERR

II CFARACTERISTICS OF THE SAMPLE COMPARED WITH THE TOTAL CLINIC POPULATION

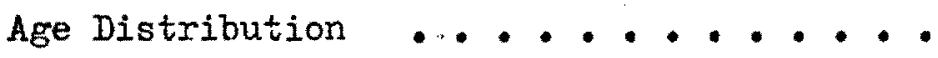

Race

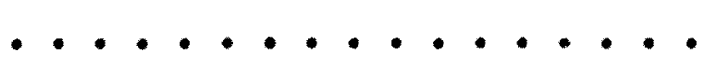

Marital Status .............

Income

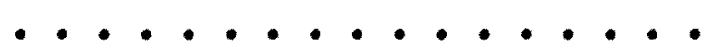

Source of Support and Living Situation ...

Children and Previous Pregnancies . . . .

How They Found out About the Agency ... .

III CGARACLEPISTICS OF RER SAMPIE CURRENT PREGNANCY AND SEOUELAE

Patient Status with PPA :.........

Contraceptive Knowledge and Dse ......

Circumstances at Time of Conception ....

Gestation .................. 
Desire for Future Children ... . . . 22

Referral Patterns .......... 22

Confirmed Outcome and Returm for Contraception ......... 23

IV RECOMMENDATIONS TO THE AGENCY .......... 25

Review of Recording ........ 25

Purposes and Priorities of Recording . . . 26

How to Get Better Recording . . . . . . 31

Clinic Self Evaluation . . . . . . 34

Some General Areas for Staff Discussion . . 35

V SUGGESTIONS FOR FURTHER RESEARCH . . . . . . 37

VI METHODOLOGY

Key to Panch Card Coding . . . . . . 41

Criteria for Adequacy: Unavailable Data . . 44

Criteria for Adequacy: Forms ... . . . 45

Data Transfer Sheet: Explanation .... . 45

Key Punching ... . . . . . 45

APPENDIX

A. FORMS

I Application for Pregnancy Counseling a . . 46 Application for Pregnancy Counseling b . . 48

II Pregnancy Report . . . . . . . . 49

III Report of Follow-up .......... 50

IV Data Transfer Sheet .......... 51

B. FIGURES AND TABLES 


\section{CHAPTER 1}

\section{INIRODUCTION}

In August of 1969 abortion became legal in Oregor. Aocut a year later, in October of 1970, the Planned Pamenthood Association In Portland began to offer pregnancy testing and counseling as part of their services. This is a new and separate progrem which is designed to help women find out if they are pregnant as early as possible (et low or no fee) and provide counseling on the problems conrected with unwented pregnancy. This counseling has resulted in a high percentage of refexrals to private physicians, the University of Oregon Medical Schoo]. and other medical facilities for therapeutic abortion (often with the help of welfare to pay the costs.) Women who plan to have the child are also referred, if they wish, to welfare for financial help, to private agencies and to medical care facilities.

This study is based on a sample of women seeking pregnancy counseling at Planned Parenthood in Portland in the calendar jear 1971. During that year about 1,230 pregnancy tests were done through the agency: of these, 549 were positive, and 681 were negative. The women whose pregnancy tests were negative, of course, did not need pregnancy counseling. They were offered regular contraceptive services and are reflected in the total clinic population. From the 549 positive tests a $20 \%$ random sample was drawn by utilizing the terminal digits of 2 and 6 in the six digit clinic number assigned evary patient. This sample numbered 113 cases: of these, 109 records were located. The present sturiy is based on data from these 109 records. 
These records axe difficult to use because they come from the fixst jear's experience with a new program, in an agency where change is occurring rapidly. Several of the forins were revised during the year. Recording in the agency was originally designed to meet the requirements of patients who came in for contraceptive services and were used, without change, for the pregnancy counseling patients. Two new forms were developed for this special group during the course of the year, with the expectation that they would be modified as experience developed.

While the ultimate concern of this study, like that of other research on contraception and abortion, is to develop knowledge useful in reducing unwanted pregnancies, the immediate purpose is to provide Planned Parenthood Association in Portland with information about the new group that it is serving. The study tries to do this by:

1) Comparing this new group with presently available statistics on the total olinic population,

2) Analysing the attributes of this special group of clients: the pregnancy counseling group,

3) Making recommendations to the agency on forms, procedures and recording which the researcher feels will improve the service to this group, and

4) Making susgestions as to further research that would develop additional information helpful in serving these clients. The major effort in this study is to display the information derived from the sample in a way which will be useful to both the agency and to others doing research in the field of contraception 
and abortion. No attempt at formal statistical analysis has been made, because so many of the sub-groups within the sample are too small to make mathematical methods meaningful. However, these small sub-groups have been regularly reduced to percentages for the purpose of making comparisons easier. Some of the larger sub-groups could be subject to statistical anaiysis in the future if desirable.

Hereafter, in this study, "Total Clinic Population" refers to all the women served by Planned Parenthood in Portland during the calendar year 1971 and is abbreviated TCP. "Pregnancy Counseling Group" refers to the 549 women with positive pregnancy tests in 1971; this is a subgroup of the TCP and will be abbreviated PCG. "The Sample" refers to the 109 cases drawn at random from the PCG. Planned Parenthood in Portland is abbreviated PPA. In the year 1971 the TCP for PPA was 6,491 women. 
CHAPTFR II

CHARACTERISTICS OF THE SAMPLE COMPARED WITH

THE TOTAL CLINIC POPULATION

Age Distribution

The sample has ages by year for those over 18 and ages by year and month for those under 18. The data for the total pregnancy counseling group has ages by year. For the total PPA clinic population of 6,491 women the age data is only available in groups of ages at five year intervals; under 15, 15-19, 20-24, 25-29, 30-34, 35-39, 40-45 and over 45.

In comparing the graphs (Figure I) of the distribution in the sample and the age distribution of the total pregnancy counseling group of 549 for the year 1971 it can be seen that the age distribution of the sample accurately reflects that of the population from which it was drawn. They both peak strongly in the 18-19 year ranges. This differs from the peak of the TCP which peaks in the 20-24 year range. When the age data for the sample and the PCG is grouped in five year intervals to correspond to the data available for the TCP the percentages for each interval are almost identical for the sample and the PCG, but these differ from the TCP which has higher percentages in the older age groups (see Table I) The mean of the PCG and of the aample are nearly identical: 20.9 years and 20.7 years respectively. There appear to be significantly more younger women in the PCG than in the TCP. 
In a recently published book on family planning ${ }^{1}$ some percentages are given for ages of women seeking pregnancy counseling in the San Francisco Bay area: $76 \%$ under 24 years and $55 \%$ between the ages of 17 and 22. The PCG sample has $82.6 \%$ under 24 and $64.2 \%$ between 17 and 22 .

\section{Education}

The educational level of the sample is less than that of the IFCP, but this appears to be the result of the larger number of younger wonen in the PCG, many more of whom are still in school. Only 11 in the sample had dropped out or were behind grade level in school. Twenty-six women in the sample had some college, ten were currently enrolled. (Table II)

There are considerably more women with college in the TCP than in the PCG sample. (Table III) There may be a large sub-group of college students in the TCP that raises the educational level of that group. If the educational standard is set at the high school graduation level then the sample does as well as the TCP. The PCG does not appear to be a poorly educated group.

$\underline{\text { Race }}$

In the sample of 109 there were 12 black women and 3 non-white women who were not black. The black women are $11 \%$ of the eample. The TCP is $8.2 \%$ black, and the black population of Portiand is $9 \%$. The black women appear as well educated as tho white and have a similar

1Lydia Rapoport and Leah Potts, "Abortion of Unwanted Pregnancy as a Potential Life Crisis", Family Plannins: A Source Eook and Case Material for Social Work Education, Florence Haselkorm, ed. (New York: Council on Social Work Education, 1971), p. 251 
age distribution. In planning for the pregnancy $58.3 \%$ of the black women choose abortion and $60.6 \%$ of the total sample do so. (Table IV) The only observable difference between the black and white portions of the sample is a higher percentage of the black women on welfare, but this may be an accident of the small sample.

Marital Status

About $80 \%$ of the sample appears to be single, divorced or separated. This data is difficult to obtain from the records. As many as $22 \%$ may be married and living with their husbands, but only $12.8 \%$ are definitely in this status. Five women indicate divorce, and two say they are pregnant by a man other than their husband. The best figure obtainable from the sample is $71.6 \%$ single and never married. The Bay Area study shows $71 \%$ single and never married and $84 \%$ unmarried at the time of the pregnancy. 2

Income

Data is available for 1) those on welfare, 2) those at HEw or OEO standards (not on welfare), and 3) income above this (able to pay the full fee) HEW standards are $\$ 6,000$ for a family of four. From the sample: $9.5 \%$ on welfare; $85 \%$ at HEW or OEO standards; and $5.5 \%$ higher income. In the TCP $9.2 \%$ are on welfare.

Source of Support and Living Situation

Information in this section has been derived from the income questions on two PPA forms. On one form there is the question "Income:

${ }^{2}$ Rapoport and Potts, p. 251 
Weekly take home pay" and the question "How many people in your family are supported by this income." On the other form there are the questions "Income", "Number of children living with you", and "Other Dependents". The answers to these questions gave data on both income and source of support and in many cases on living situation as well. of the sample of 109 there were 93 cases in which there was enough information to make a classification in this area.

The data is most meaningful by classification into three groups: those in the family of origin, those in a family of emancipation and those living on their own earnings. (Table V) In the family of origin the girl is essentially supported by relatives of the parent sort, in the family of emancipation, she is supported by a husband or boy friend, in the third group she is self-supporting and may live either alone or with parents or spouse.

The data shows a relatively sharp break in living pattern occurring between 18 and 19-a time that, for most, marks the completion of high school.

Most of (78\%) the young women 18 and under were living in a "family of origin": i.e., dependent on their parents financially, physically and legally. Only one 17 year old was self supporting. Although four firls under 19 listed themselves as married, only one was being supported by her husband. Two young women had moved from parental dependency to welfare dependency, with themselves as parents. Most were still in high school. Five had graduated and secured employment.

The 19 to 40 group had finished high school and most of them were emancipated in a practical sense. Six (11.4\%), mainly college students, 
were still dependent on the family of origin. Over one half (53.8\%) were supporting themselves completely. An eighth were the family wage earner, supporting dependents. Although one third were listed as married, only one fourth had a working husband or boy friend. A twelfth were parents in ADC grants.

The important characteristic of the older age group is their relam tive situational ability to make their own decision about pregnancy if they can manage the financial aspects. Even though an unmarried 19 year old requires parental consent in Oregon, she can, by procuring a local Washington address, arrange a therapeutic abortion in that state without involving her parents.

\section{Children and Previous Pregnancies}

Table VI is titled "Reproductive History". It displays the data having to do with previous pregnancies, previous abortions, previous live births, children that have been released for adoption, and children with the mother. The only data that is available from the total clinic population is the number of live births. No member of the sample had more than four previous pregnancies, more than four previous live births, or more than one previous abortion. Five of the women had released children for adoption; one of these had released two children.

On examining this table, it can be seen that only two women in the age group 18 and younger have children with them. One of these women has one child and the other has had two children, releasing one. These are the same two women that appear in Table $V$ in the category "welfare adult18 or under". They account for the three live births in that section of Table VI and for three of the seven pregnancies in the section "previous 
pregnancies". Four others have been pregnant; two had abortions and two miscarried. For all the rest of the younger group (over $85 \%$ ) this is the first pregnancy.

Half of those 19 and over have never been pregnant before. Less than $40 \%$ have ever given birth to a living child. Four have been aborted and two have miscarried. Of the 24 women who have had a child half have only had one.

On the other side there are a small number of women, 13 in all, with from 2 to 4 children. Although these women constitute a rather small sample, their presence might indicate a group with problems of desired family size. The situation for them may be very different from the $75 \%$ of the total group who are childless and mostly single. Some of the differences will be discussed later in the decision section of Chapter III.

The Fact that six women have had previous abortions and that five have released children is interesting, but a larger sample is needed to know whether this represents the percentage to be found in the total PCG. These groups merit further study, particularly considering the ages of the women involved. Mean age of the women with previous abortions is 22 years 4 months. The mean age of those who had released children for adoption is 21 years. The largest portion of their reproductive life is still ahead of them.

How They Found Out About the Agency

This is the last factor on which there is information from the TCP. All patients who cone to Planned Parenthood are asked how they learned about the agency. This factor is classified into five categories: 
1) other patient, friend or relative; 2) self: that is, they heard about Planned Parenthood by reading about it or from publicity on the radio or television; 3) by referral from a school or social agency (not necessarily a formal referral, but at the suggestion of a welfare worker, juvenile court counselor, school counselor, etc.); 4) from a hospital, clinic or physician; 5) as a result of the activities of Planned Parenthood personnel (they may have heard a PPA speaker, or attended a meeting sponsored by PPA).

Table VII compares these five categories for the total clinic population and for the sample, with the sample divided into those who are 19 years and over and those who are 18 and younger. The largest classification for all three groups (total clinic, older and younger) Is that of finding out about the agency from a friend or relative. Here the older groups percentage (64\%) approximates the percentage of the TCP (62.8\%); but the younger group indicates $81 \%$ as referred by friends and relatives. This is probably a significant difference since the number in the group is 39.

It may be that the total clinic population would also show this high a percentage for the younger age group if taken separately and that the $62.8 \%$ in this category for the TCP is a reflection of the higher mean age.

Though there is some suggestion in the table that the older group is more often referred by medical facilities and the younger group by socjal. agencies, the numbers are too small to be conclusive. This would be an interesting area to explore with a laxger sample.

The important factor is that over $80 \%$ of those 18 and younger come to the clinis because of word of mouth information. One of their friends 
or relatives is a PPA client or has friends who are PPA clients. No one says they came because of hearing an agency speaker or other contact with agency personnel. Seemingly planned Parenthood efforts to inform prospective clients of available service are not reaching or registering on the sexually active minor, or at least those who get pregnant. 
CHAPTER III

CHARACTERISTICS OF THE

SAMPLE CURRENT PREGNANCY AND SEQUETAE

This chapter focuses on information relating to the current pregnancy of the women in our sample. Also included is information about contraceptive knowledge and use, and the outcome of the patient clinic contacts as to decision, plan, referral, outcome and return for contrar ception.

\section{Patient Status with PPA}

By patient status is meant: is the patient one of the regular PPA continuing clients who has become pregnant, or is her coming to the agency for pregnancy testing and counseling her first contact with the agency? It is actually not quite this simple, because the data can be divided into four groups. There is complete information for the sample of 109. Eighty-three patients or $77.1 \%$ were new to PPA. Sixteen pam tients or $14.7 \%$ were old patients; i.e. clients that had been coming to the agency as regular contraceptive patients. There are three par tients in the category "previously known" who were not current clients of PPA. Two of the three in this category had been known to Planned Parenthood ilinics in other cities; one had just retumed to Portland after a long absence. She had been a previous client of Portland PPA. There is also a group of seven women that could not really be classified as new or old: henceforth identified as "in betweens". These are women 
who had become PPA clients shortly before coming in for pregnancy testing. These patients may have been pregnant when they came to the clinic for contraceptive services, or they became pregnant shortly after this visit and before regular contraception had been established. They are all women who did not have a menstrual period subsequent to their visit to Planned Parenthood for contraception. They are more appropriate to the new group than the old group, except for the fact that a contraceptive intent is established at a time previous to the visit for pregnancy testing, and we know that they have had some instruction in contraception. Table VII shows these four status groups: the total for each group, and the number who are 18 and under, and 19 and over for each group. The mean age of the group of new patients is 19.2 years; that of the old patients is 23.6 years. The "in between" group of seven pam tients has a mean of 16.9 years, and the previously known group has a mean of 24 years. Adding the "in betweer" group to the new patients reduces that mean age even further.

The very young average age for the "in between" group may indicate that these are women who have just become sexually active. They have probably become anxious about pregnancy and have come to the clinic a little too late. The older mean age of the "old" patients would correspond to the data on the TCP which has more older women in it than the PCG (see Table I) Figure II is a graph of the total sample with the "in betvisen" group and the combined old and previously known groups shaded (each differently) to show how these two groups are distributed in the total sample. The graph shows that the number of new patients drops off after the age of twenty-two. Thus, the women who come to 
Planned Parenthood for the first time already pregnant (the new and in between groups combined) have an even lower mean age than the PCG as a whole.

Contraceptive Knowledge and Use

Although contraceptive knowledge and use relative to unwanted pregnancies was the single area of greatest interest to the researcher, it proved to be the most difficult area in which to collect meaningful data. The problems were multiple. Though 83 of the records had forms filled out by the clients where they could report on knowledge and use of nine methods of contraception, there is no method on which there is complete data. Additional information had to be taken from any place else in the record where knowledge or use of contraception is mentioned. This means that the sample size varies from item to item, and that this increase occurs for positive information, but not for negative information. Nevertheless, it was important to get the information in. Use reports tended to discriminate against the unreliable methods (rhythm, withdrawal, douching) because some interviewers will not list these as contraceptive methods at all. There is also a bias in favor of maximum reporting of pills and perhaps the IUD because some patients do not use the fancy word "contraceptives" for simple old-fashioned techniques like condoms and douching. They are more likely to use that word only for something prescribed or installed by a physician.

To secure good data in this area would require trained interviewers who could also explore the adequacy of knowledge, since knowing of or even using a method does not necessarily equate with knowing how to use the method correctly. 
The information available appears most meaningful when divided by the age groups: 17 and under, 18, and 19 and over; arranged by knowledge, use, and use relative to the conception that brings them to the clinic. (Table IX)

The records show, as might be expected, that both knowledge and use of contraception increase with age. Knowledge of a method's existence is much greater than the use of that method. Pills are the best known method, by and large, ranging from $70 \%$ at 17 and under to $98 \%$ at 19 and over. There is rapidly increasing knowledge and use of contraception during the eighteenth year, with considerable contrast between 17 and under group and the 19 and over group. (Table IXB) Condoms, a male non-advertised method, are the best known (80\%) at 17 and under, and the knowledge of that method does not significantly increase with age. Withdrawal and rhythm which have high frequency at 17 and under along with condoms are really methods of male responsibility. By the time the sample reached the age of 19 and over female methods (pills, IUD, foam) occupied the first three places with condoms fourth.

This might suggest that the younger girl, beginning an active sex life, depends on her partner for contraception. Moreover, the low use and knowledge of non-pill female methods, particularly foam--which is widely advertised and non-prescription, may suggest an emotional barrler, more prevalent in the younger girl, to utilizing or considering any practice involving her manipulation of her own body.

It is possible that many girls do not really retain contraceptive information until they have discovered a personal need to know, and that their initial knowledge may be derived from their sexual partner. Perhaps, 
in some, it takes a fright of possible pregnancy to overcome emotional barriers and make the use of female methods more acceptable. Thus the seven "in between", who had attended a contraceptive class while posgibly pregnant, recorded a higher degree of both knowledge and use of female contraception than the average of the other girls 18 and under. Rhythm, the most popular method reported as having been used by 40-50\% of those 18 and under is likely to only designate intent. Rhythm is, at best, an unreliable method, easily misunderstood, which requires complicated calculations, great self discipline, and a regular menstrual cycle, not characteristic of younger girls. 3

Pills and the IUD, generally considered to be the two most reliable methods, have been used at one time or another by almost half the women on whom we have data; and, even without any information on twelve par tients, $42.3 \%$ of the total sample have used one of these methods. Table X reflects the fact that of the 47 women in our sample, whom we know have either used pills or the IUD, only six were 18 or younger. Seventeen percent of those who have used one of these two methods have had to discontinue on medical advice; $25 \%$ have stopped the method on their own. On $36.2 \%$ there is no information in the records as to why they discontinued use and the remaining $21.3 \%$ will be discussed below.

\section{Circumstances at Time of Conception}

The very poor data available on contraception at time of conception is shown by Table XI. There is no information on 38 women out of

3 see Elaine C. Pierson, Ph.D., M.D., Sex is Never an Emergency (2nd ed.: New York: J.B. Lippincott Co., 1971). p. 8. and David B. Van Vect, Ph.D., How and Why Not to Have That Baby (New York: Paul S. Briksson Inc., 1971), p. 43 . 
our sample of 109. For the 17 and unders there is no indication of contraceptive failure using a reliable method, but $19.7 \%$ of the sample of 31 indicate that they were using rhythm or withdrawal. There are three method failures of a reliable method in the seventeen 18 year olds and two rhythm/withdrawal failures, of those 19 and over $24.6 \%$ are classified as becoming pregnant using a reliable method and another $9.9 \%$ using rhythm and/or withdrawal.

It should be recognized that the clinic data on contraception at time of conception is even poor on the 18 women $(16.4 \%)$ who report method failures on reliable methods. For the majority of those 18 clients, there is no information as to whether the method failed under proper use, or if there was patient failure in not following directions properly. This is especially clear in the cases of the six IUD "failures"-the record shows two "in place" but is not clear about the other four. The four pill failures appear to be petient errors, but the exact nature of the exror is unclear in two cases. For instance, what does "messed up on pills" mean.

The lack of adequate data on contraception at time of conception is not a result of poor patient reporting on forms. At present, all such data is collected in the interview. It is the interviewers who either did not get the information or did not record it.

The records, however, specifically indicate that $45.2 \%$ of those 17 and under, $41 \%$ of the 18 year olds and $24.6 \%$ of those 19 and over are reported as not using any preventative at the time of conception.

\section{Gestation}

If a pregnancy is terminated by a properly performed abortion within 
the first twelve weeks the risk to the health of the mother is less than any of the possible outcomes of the pregnancy aftex twelve weeks, including giving birth to a living child. 4 Abortion is cheapest under ten weeks. There is a period between about 13 weeks and about 16 weeks when a phyalcian will not ordinarily perform an abortion, unless a hysterectomy or tubal ligation is also being done. ${ }^{5}$ Then between about 16 and 21 weeks (150 days) an abortion can be performed by the nore expensive and riskier saline method. There is data accumulating from psychological studies that the earlier an abortion is performed the less the psychological stress on the patient. Also, saline abortions may carry increased risk of iatrogenic psychological damage to the patient because of the longer exposure to the negative feelings about abortions of nursing and other medical personnel (and the later the abortion the greater the feelings). 6 Most of the data on gestation is based on menstrual history only. There are 8 cases without gestation data, producing a reduced sample of 101. Table XII shows weeks of gestation (rounded to the nearest week) at the time of pregnancy test, by age $(14-18,19-20,21-40)$. Two of the youngest age group were too far along for abortion; 8 more were in the saline period; and 17 of the youngest group were at 10 or 11 weeks. By contrast, there were only 4 women in the 19-20 group and 1 in the 21-40

4 see Alan Guttmacher, M.D., Birth Control and Love (1969 revision: New York: Bantam Books, 1970), p. 177 .

5 see Irvin M. Cushner, M.D., noutcomes of Induced Abortion: Medical clinical Vjew", in Hasalkorm, p. 129

6 6 see Rapoport and Potts, pp. 261-264., also Leon Marder, M.D., "Psychiatric Experience with a Liberalized Therapeutic Abortion Law", American Joumal of Psychiatry, Vol. 126, No. 9 (Merch 1970) pp. 1230-1236. 
group in the saline period. One of the 19-20 group and 5 of the 21-40 group fall in the 10-11 week range. The one woman in the 21-40 group who would require a saline abortion was just 21. The table indicates that the older women are much better about seeking help with their unwanted pregnancies early enough for safe and economical abortion.

Table XIII shows that all but one of the women who were using a reliable method at the time of conception sought help with their pregnancy within nine weeks of their last menstrual period. The one exception had bleeding at the time of her regular menstruation and came in at six weeks by her own figuring of menstrual history. This may be related to age, or may reflect that those women who are knowledgeable and motivated enough to use a reliable method of contraception are also knowledgeable enough to seek early pregnancy counseling.

Table XIV is an analysis of the "in between" group from the discussion under patient status. This appears to be a group of women (7) who are just starting their sexual life. All of these girls (mean age 16.9 years) came to the clinic for contraceptive service prior to missine a menstrual period. Pills were prescribed for all of them, and they were given foam and condoms to use until the next period when they could start the pills. As previously stated, this is an age group of considerable menstrual irregularity. All of this group did not come for pregnancy testing until from 11 to 16 weeks. It seems probable, that the combination of being reassured that they were "doing something" now, and the irregular periods of this age group account for the lateness of their contact with the agency for pregnancy testing.

The agency should be aware of the young patient who may be preg- 
nant at the time of first contraceptive visit. This matter will be discussed further under Recommendations to the Agency.

Decision

Data on decision have been classified into the following categories; decision to: 1) obtain abortion, 2) abortion plus sterilization, 3) keep the baby and get married, 4) keep the baby (already married) 5) keep the baby while single, 6) have the baby and decide what to do later, 7) undecided. There was a category prepared for releasing the child for adoption, but no one in the sample of 109 made the decision to have the baby and release it.

The sample of 109 contained only three known planned pregnancies. In one of these an 18 year old single girl decided for an abortion because of a changed relationship with the father. A second 18 year old decided to have and keep the baby without marriage. The third, a 20 year old woman, was married and had a desired child.

Table XVI shows decision by age, with age grouped: 14-18, 19-20, 21-22 and 23-40. The table shows that the older the woman, the more likely she will decide on an abortion. The only women (3) who decided to keep the baby in the 23-40 age group were already married. Almost all the socially problematic decisions were in the youngest age group. Table XVIII shows how the "get married and have baby" decision decreases with age. The nine girls who say they will remain single or decide leter and have the baby are all in the 14-18 year group, except for one in the 19-20 year group.

Table XIX shows that four of the six women who had previous abortions decide on another abortion; while two who are both married will 
haye the child. Four out of the five women who previously released children choose an abortion this time.

Tables XX and XXI show decision by marriage status. Single women who are 78 out of the 109 show a therapeutic abortion rate of $62.8 \%$. They also make all the complicated and socially problematic decisions: to marry and have the baby, have and keep the baby while single, have the baby and decide later. This group also includes all the known "undecideds". The mean age is 19 years for single women.

The 31 women known to be or have been married either choose abortion or to have and keep the baby in an existing marriage in the 27 cases on which there is data. All the known divorced women and the two pregnant by someone other than the husband elect abortion.

In the married group, some of the decisions to have the baby undoubtedly reflect either planned pregnancies (one is definitely planned) or pregnancies where the couple planned to have the taby if she should "happen to get pregnant". There are ten decisions to have the baby in this group. The mean age of the women who are married and elect to have the child is 21.3 years while the mean age of those who choose abortion is 24.2 years. The apparent general trend of the sample is increased abortion with age.

Table XXII shows that of the 15 women who say they do not wish to have children in the future, 11 decide for abortion. One of the 15 decided to keep the child and on 3 there is no decision data available. The mean age is 25.9 years.

Tables XXIII and XXIV show that those women who have had children and those who have dependent children at home choose abortion somewhat 
more often than the childless group, of course, this is also correlated with age: mean 23.7 .

Table XXV separates out the group that have had a contraceptive failure with a reliable method from the rest of the sample and shows the two groups by decision. The contraceptive failure group has a somewhat higher preference for abortion, also a higher mean age, 23.8. Thus, throughout the study, older ages correlate with such things as children, use of reliable methods, marriage, etc. and also a higher abortion rate.

\section{Desire for Future Children}

The PPA interviewer is supposed to ask all clinic clients, including the PCG patients, if they desire children in the future. Table XXVI gives the data on this question. of the 83 women asked, 63 or $75.9 \%$ wanted to have a future child. In 26 cases of our sample of 109 , the interviewer either did not ask or did not record on this question. It is interesting to note that the failure to ask this question is much more common in the records of the younger patients. The rest of the table reflects, as we might expect, the older the client, the more often there will be the decision not to have children in the future. Table XXVII shows that $73.3 \%$ of those who do not want future children already have children at home.

\section{Referral Patterns}

Table XXVIII shows referral by decision. Only the primary refemal is tabulated. Of the sample of 109 there are 43 cases in which referral is not recorded. This does not include the category of "no referral". Referral recording is by far the best for those women who decide for 
abortion, where $73 \%$ are referred. The table shows that about half the referrals for abortion were to private physicians, with another $17 \%$ to other medical facilities. The welfare referrals under decision to abort will probably also go to private physicians, with welfare paying the costs. Referrais are only recorded for $29.5 \%$ of married women having the baby and $50 \%$ of those having the baby while single.

Confirmed Outcome and Return for Contraception

This section is on the question: is there anything in the record to indicate what actually happened after the decision, plan and referral were made? In 91 of the 109 cases, or $85 \%$, there was nothing in the record on outcome. It is my experience from working in the agency that there is, in fact, considerably more feedback to agency personnel as to the outcome of individual cases than this, but that the information does not get recorded.

of the sample of 109,14 or $12.8 \%$ returned to the clinic for contraceptive services after the therapeutic abortion. Two also returned for contraception after having the child which they kept, and an additional two returned after spontaneous abortions. In all 19, women returned for contraception. PPA records give no explanation of what happened with the 19th pregnancy, though because of time factors, it can safely be prem sumed that the patient either spontaneously aborted or was legally terminated.

The mean age of those who returned for contraception is 19.9 years as against the mean of 20.7 years for the total sample. Another $20 \%$ were classified as not due back, within the time of the collection of the data, or not due back at ail because of sterilization. This still leaves $60 \%$ 
unaccounted for, including $68.8 \%$ of those 21 and younger. 
CHAPTER IV

RECOMMENDATIONS TO THE AGENCY

The present PPA recording system was designed for contraceptive patients with adaptions made to meet immediate short range needs of a rapidly changing and expanding agency, rather than for research. Because material was not available for retrieval does not mean that the factors were not given full attention at the time of patient contact. Throughout my experience with PPA, I have been aware of the high concentration on patient service and the complete dedication of the staff, both professional and voluntary, to providing high quality patient care. The small percentage (14.7\% or 16 cases) in the sample of 109 pregnancies, for ongoing clinic patients is evidence that the clinic has been successful in meeting its first goal of providing good contraceptive services.

On the assumption that most regular contraceptive patients who become pregnant without wishing to be so, return to PPA for pregnancy verification, a figure of 16 from a $20 \%$ random sample would indicate approximately 80 pregnancies a year among over 6,000 contraceptive patients served by PPA in 1971.

\section{Review of Recording}

The most important and general problem seen is the need for a full evaluation of the present recording system, as it concerns the pregnancy counseling group, in terms of purpose, efficiency, recording responsibility and procedures. 
A complete evaluation of recording has probably been of relative low priority for the agency. Forms have been added and altered under the pressure of immediate need. During the last year, there have been substantial overall improvements in recording for regular clinic patients and the improved medical history. However, none of these forms really help much in meeting the unique challenge and opportunities afforded by the pregnancy testing and counseling program.

Purposes and Priorities of Recording

In using the records of a social agency to gather information about its clients for research purposes, there is a danger that recommendations on recording will focus on research needs rather than the other purposes of the record. The primary purpose of the record is to help those who have contact with the client to provide services of good quality and continuity. Such records may also then be used for other purposes, which are just as important to the agency in the long run, but have less immediate impact on the clients. These other purposes incluae: accountability to justify the expenditure of funds, the evaluation of staff, teaching and staff development, and research. This research can be either on developing information about the clients served or about the functioning of the agency. The research in this study has been directed toward learning about the clients, but it has, as a matter of course, also produced information about agency functioning.

Though research has been the focus in the use of the records of the pregnancy counseling clinic, the problem of the adequacy of the records for research purposes will be left to the last. First an examination will be made of the kinds of things that the records must contain to assure 
continuity and quality of service to the client, beginning with four areas where, in the sample of 109 pregnancy counseling patients the records have varying degrees of inadequacy. In these four areas, it can be argued, good recording is, itself, essential to insure quality of service.

Recording must be clear in meaning so that the next person who sees the client will have an accurate account of what transpired on the last visit. Assumptions based on inadequate recording are often wrong and clients can easily be hurt in matters involving their sexual Iife.

To serve the PCG client well, the record should document the following in every case: 1) the contraceptive circumstances under which conception occurred, 2) the plan decided upon by the patient-even when the plan must be shown as "undecided", 3) the referral, or referrals-including the decision of "no referral"-made for the client, and 4) the stage of gestation at the time the client comes to the agency. Table XXIX shows the number of records where no data was available In each of these four vital areas. Ten records out of the 109 gave no indication of the plan arrived at; 43 nothing about referral; 38 had no information on whether the patient was, or was not, using or trying to use a form of contraception at the time of conception; and 8 records out of the 109 contained no data on the stage of gestation of the client when she canie to the agency,

The research shows a rather consistent rate of 9 omissions for every 10 cases throughout the year in one of the four areas under consideration. This does not mean that only one case in ten is complete 
because some cases have two or more omissions. For the total sample of $109,37.6 \%$ of the cases were complete in the four areas.

Recording omissions in one or more of these four areas raise questions in demonstrating the quality of service to clients. To make a good referral, it is essential to not only know the plan the client wishes to follow, but also the stage of pregnancy.

Cases were counted as inadequate when there was no last period recorded and no exam estimate. Actually, for the youngest clients, who may be very irregular, menstrual data should include the penultimate period as well as the last and information on irregularity. Neither of these things are currently recorded. If possible, gestation should be confirmed by examination in the younger age group.

Because abortion techniques and problems are determined by gestam tion, the referrer needs the best available estimate of gestation to determine the type of abortion required and whether the case should be given a rush priority to avoid the more dangerous and costly saline abortion when the safer and more economical $D$ and $C$ is still feasible. Border-line cases should have the highest priority because of the time factor. A teenage girl, who comes in at six weeks has more time in which to delay informing her parents while she explores her feelings than one who comes in at 11 or 12 weeks. The time it takes to schedule hospitalization must be considered, if a saline abortion. is to be avoided. Although saline abortions can be performed up to 150 days of gestation, the problem of hospital scheduling means that a girl who comes in at 20 weeks is right at the limit for any abortion at all. There is also the difference in expense relative to gestation at 
the time of abortion, which is information the client needs in contemplatine arrangements.

Circumstances of conception are important to know so that referral may also include a plan for help with birth control after the abortion. The various places where the client can be referred for abortion will vary as to how well they follow-up with contraceptive services after surgery. If the patient is already skilled in contraceptive practice and the pregnancy was not a contraceptive failure (but perhaps planned with a subsequent change in social circumstances) then follow-up on contraception may not be necessary.

The patients with contraceptive failures would seem to be partIcularly in need of an opportunity to review what happened. If a misuse or misunderstanding of the method is involved, clarification may help them to be more optimistic about future contraceptive reliability. These patients and those for whom the method clearly failed offer a compacted group that the agency can use in evaluating the success of its instruction program.

A good referral record can be used to point to areas where referrals are not being made. The data indicate that women who decide to have the baby may not be receiving as much help in locating medical assistance as those seeking abortions. (Table XXVIII)

Tabulation of the number and type of referrals can be utilized by the agercy to demonstrate one area of accumplishment. In fund raising and in relationships with other agencies a record of specific accomplishment rather than assumed accomplishment is immensely valuable. The agency needs not only to be able to say that it has a program, but to show the community what the program does. 
If the records are to have maximum usefulness for the agency, they must be designed with an economic way of information retrieval in mind. Data needs to be complete and recorded in a uniform fashion that will allow efficient access and analysis. Individual patient records may be excellent in content but they are of no use to the agency beyond the care of that patient unless the information is accessible and forms part of a connected body of information that is conducive to analysis of a total group or compilable as a record of agency service. Therefore, it is necessary that records become more specific so they can be classified into groups. Pregnancy tests are sometimes done for other purposes than pregnancy counseling and the records of such cases should not be included in evaluating the pregnancy counseling Group. Example: Case No. 719942 is a married woman who had had a previous abortion. She may have come in with a planned pregnancy to share her good feeling about her present situation with a staff who had helped her in a previous crisis. The record was classified as unavailable for contraceptive data because other than confirming pregnancy there is only the word "happy" written across the counseling form.

Also, an occasional patient may appear for rapid pregnancy verification for welfare eligibility rather than counseling. Such may be the situation in record 719556, a young woman who could perhaps benefit from other services. A notation that the test was done only for verification could be used to eliminate this record from the counseling group.

Partial records could be explained and eliminated if the circumstances were recorded. For example: a young woman who leaves before recelving the results of her positive pregnancy test and does not return 
need not be counted a counseling patient.

Closed cases need to have entries which account for the closing. There is a difference which should be clear between a case closed because the woman has had a tubal ligation at the time of abortion and an 18 year old girl who has released one child and aborted another and whose whereabouts are unknown. Clear accounting of closing would allow better calculation of patients who should be expected to return.

If cases which should be followed elsewhere for contraception on the basis of referral are eliminated along with those closed, it might be possible for the clinic to eventually do some selected outreach and follow-up.

How to Get Better Recording

Under the present system, information relative to the current pregnancy is distributed over a number of forms: especially the Medical History, Application for Pregnancy Counseling, Pransfer Sheet for Automated Data, Pregnancy Counseling Form, and Medical Referral duplicates. There seems to be no clear cut area of responsibility for what minimal information is to be recorded by the several people involved. In addition, the regular clinic forms were not designed with areas designated for some of the information necessary only for the pregnancy counseling patients. Both the physician and the social worker make referrals. All these things probably contribute to the deficits in recording.

The Pregnancy Counseling Form is directed at psychological rather than circumstantial information. In 1971 the use of this form appeared to be optional, because in 52 of 109 cases (47.7\%) it was missing. For this form: in 35 or $32.1 \%$ of the cases it was present and adequate and 
in 22 or $20.2 \%$ of the cases it was present and inadequate. The new revision of the Pregnancy Counseling Form is even more weighted toward patient psychological factors.

Form IA and Form II show the suggestions for immediate changes in the recording system for patients having pregnancy tests. Form IA is a substitute for the present agency Application for Pregnancy Counseling which is filled out by the patient. Besides some improvements in wording, the patient would write down additional information on dependency on parents and provide some data on any efforts to prevent pregnancy since the last menstrual period.

Along with the economy of using the patient to provide some of the recording, the questions on contraception are meant to give the client a message that the error of her pregnancy, if there is one, may lie in her contraceptive practice rather than, what is for most PCG clients, premarital sex. Throughout the course of an unmarried pregnancy, regardless of the decision made, the woman, especially the minor is likely to receive the messace that people are willing to help her this time and that they hope she has learned a lesson. The basic problem, as research reveals, ${ }^{7}$ is that unless the woman accepts her own sexual needs and behavior, she is unlikely to become an effective contraceptor. Consequently, women are Iike ly to have repeat unwanted pregnancies, because sex must "happen" to them without intention on their part. With ome information on the client's prior knowledge and use of 7 Leah Potts, "Counseling Women With Unwanted Pregnancies", Family Planning: A Source Book and Case Material for Social Work Education, Florence fiaselkom, ed. (New York: Council on Social Work Education, 1971), p. 277 
contraceptives, the interviewer has a basis on which to focus, which may increase the efficiency of the interview. Efficiency should be considered in the context of the necessity of referring women elsewhere for pregnancy tests because there is no time for additional counseling of patients.

Form II is a checklist to be completed by the interviewer which could provide a summary of information considered essential-there is no present equivalent.

When, as at the PPA clinic, many different people do counseling, a regular recording system offers a way of assuring that every patient is in fact given the same coverage, and that no important factor is accidentally omitted. This form offers the interviewer an easy checklist which she can use to assure herself that under the pressures of time and an emotionally charged situation, the client has been given an opportunity to evaluate important factors bearing on her situation. Where the interview is too stressful to discuss the factors listed, there would presumably be a note on follow-up plan. Such a checklist would also be helpful in training and evaluating new volunteers in the counseling program. Form II is largely self-explanatory. If one person were given the responsibility of reviewing all forms before filing, the clinic would shortly have complete information.

The same procedure of interviewer and single checker has provided complete information for the present automated data system. If the form were made up on duplicating paper like the medical referral slips, one copy could be filed in the patient record. The other copy could be kept in a separate file of PCG patients which would allow the clinic ready 
access when information on this clinic sub-group is desired, without necessity of searching the main files. If desired, the information could easily be sampled and key punched. This is particularly desirable, because the automated data system is not designed to deal with "pregnant on arrival", and is not collecting information on contraceptive failure or method discontinuance in unplanned pregnancies, although the need for this information is recognized. Since the only client-identifying information on the pregnancy report is the clinic number, data could be compiled without worry about loss of confidentiality.

Form III is a simple sheet to be kept at counselor desks so that follow-up information gets into the record. In sampling 109 cases, the impression remains that not more than 2 or 3 had any information on counseling contacts after the first visit. In discussion with counselors, it is apparent that they have repeated contact with patients and that many clients return or call after therapeutic abortions. The problem appears to be that the counselors rarely have time to pull the total record to make notes and no other system has been devised as yet.

Besides providing information on the outcome of the pregnancy and client reactions to the program, some kind of recording is necessary to document the time and quality factors of clinic follow-up so that the agency can anticipate staff needs and set priorities.

\section{Clinic Self Evaluation}

The A 56 Page Proposal for a 1971/76 Plan for the Planned Parenthood Federation-Pre-digested by Lee Minto proposes, as a part of nobjective I (direct services for voluntary fertility control)" that clinics and affiliates "set standards of excellence in clinic services through use of 
new techniques and clinic evaluation research." It might be possible for PPA to get Federal money for someone to set up a good information retrieval and data processing system for the clinic. For instance, the National Institute of Child Health and Human Development is funding research in the family planning area.

Failing such a grant, the clinic could consider procuring a graduate research student to develop such a project, in order to meet his degree requirements.

\section{Some General Areas for Staff Discussion}

What information should be in all records? What are the best procedures for securing uniformity and completeness of essential information? Some suggestions have been made; such as the pregnancy report, but there may be important areas that have been missed in this study. Some of the recomendations may be found inappropriate for actual use in one way or another.

Should the clinic set up some priorities for PCG intake? It appears that many prospective patients are being referred elsewhere for pregnancy tests because PPA is receiving more calls than staff can handle under present arrangements. Are there alternatives?

Among the sample of 109 there were 7 girls who made an initial visit for contraception and later returned pregnant with a last period prior to the contraceptive visit-average age 16.9 years. The problem was that they waited and returned from 11 to 16 weeks of gestation. (Table XIV)

What instructions are presently given to the girl who has been sexually active since her last period without contraception? Would it be feasible to schedule a return visit for a pregnancy test at the time 
of the original visit if the girl has not had a period by a specified date?

In the sample of 109 , there were 15 women who stated that they did not want future children. Most elected therapeutic abortion. Is ligation regularly discussed with women with children who say "no" to the idea of another child? Should it be? Two of this group did have ligations, and two husbands had vasectomies.

Would it be worth while to always ask the patients reporting past pill use where they secured the pills. The automated data sheet assumes that they are prescription and there is suspicion that for a number of PPA patients the source of previous pills was non-medical. Such information is sometimes recorded, but not regularly asked for. 


\section{CHAPTIER V}

\section{SUGGESTIONS FOR FURTHFR RESEARCH}

PPA should explore possible Federal funding of contraceptive research to see where there are areas of research of learning value to the agency.

PPA should utilize regular ongoing patients with unplanned pregnancies to provide information for the client education program. Information gained from these patients can be helpful in teaching new patients.

Method failures among women using reliable methods need to be thoroughly explored.

Why do women abandon reliable methods? In the sample there is no information on $36: 2 \%$ of women who had abandoned a reliable method as to why they did so.

There is a need for study of women who have repeat abortions. Those who have had an abortion and are again carrying an unwanted pregnancy, and decide to have the baby, should also be studied.

How do women develop knowledge of contraception?

What constitutes adequate knowledge for actual practice?

Initial knowledge in younger women seems to be derived from their male partners-is there need to focus some real education efforts on the younger male?

What are the factors which produce longer gestation before seeking counseling in younger women? 
In view of "Right to Life" pressure for return to stringent abortion laws, sensitive inquiry directed at women who have previously released a child and who are now seeking legal termination of a subsequent pregnancy might be fruitful.

PPA also needs information on the nature and type of follow-up being done on PCG clients, for instance: what percentage of the PCG requires and receives post abortion counseling? How much time is being spent or should be spent on such counseling? What percentage of cases require more than one interview before referral? Are some women being seen who have a need to work through emotional problems after abortion or delivery? If there are such women and they are not being seen, are they being referred? Where? 
CHAPTER VI

\section{METHODOLOGY}

Although no master list of PCG patients was compiled by PPA for 1971, the individual slips from pregnancy tests were saved. These were sorted into positive and negative reports. The positive tests were arranged by age and consecutive clinic numbers. After noting that the last digits from $0-9$ appeared to have equal frequency 2 and 6 were selected by drawing from ten slips of paper.

The actual study was begun by examining fifteen cases from the pregnancy counseling Eroup selected at random from the sample for the purposes of securing a preliminary idea of what kind of usable informam tion they contained. The goal was to limit the data per case to what could be punched on an 30 space punch card. As it turned out, 51 slots were used. Effort was made to select categories in such a way that the various kinds of data could be put in exclusive classifications. After establishing the original categories, a few new codings had to be added along the way, but fortunately there were sufficient numbers available to make this possible.

Some of the data that was collected was not used. For instance, age by month was recorded for the group under 18 years old, but it was found that there was little need for this information. Another category "too late for abortion" was eliminated because the information appeared automatically as a part of the data on gestation.

The following three pages are a copy of the key for punch card 
coding. They are relatively self explanatory and show how the data was ordered into categories and coded. 
KEY TO PUNCH CARD CODING

(1-6) Clinic number.

(7-8) Month pregnancy test done.

(9) Patient status. 1=new, 2=on going patient, not pregnant at the time of visit to the contraceptive clinic, $3=0$ n going patient, possibly pregnant at time of visit to contraceptive clinic, $4=$ previously know PPA Portland or PPA other city.

(10) Marital status. 1=gives maiden name only, $2=$ gives married name only, $3=$ gives married name and indicates divorce, 4=gives married name, but is pregnant by someone other than her husband.

(11) Race. 1=white, 2=black, 3=American Indian, 4=SpanishAmerican, 5=other, $0=$ no data

(12-13) Age in years

(14-15) Age in months when $(12-13)$ is less than 18

(16-17) Education (a) years completed in school up to 17

(18) Education (b) if (16-17) is less than 12 and (12-13) is 18 or less then: $1=$ student (self report), $2=$ presumed student up to grade level, $3=$ dropped out or one year behind (not 1 or 2), $4=$ dropped out or two years behind (not 1 or 2). Obtained by using November 15, which is School, District No. 1 cut-off date. $9=$ None of the above.

(19) Education (c) If (16-17) is 12 or more and client lists self as student, $1=y e s, 2=$ no or other.

(20) Income (type) 1=welfare, 2=HEW or OEO, not welfare, 3=above HEW, $0=$ not available.

(21) Support (source) 0=unavailable, 1=welfare only, 2=welfare plus employment, $3=0$ wn earnings only, $4=$ husband or boy friend, $5=$ parents or other non-spouse type relative, 6=own eamings plus husband, 7 =own earnings plus parent, etc., $8=0$ ther.

(22) Dependents (a) If (21) is 3, then number of individuals dependent on client's income $(1$ to $8+), 9=A I I$ cards $21-3$ not punched.

(23) Dependents (b) Dependent children living with the client (0-9+) (may include adopted and step-children)

(24) Live births $(0-9+)$

(25) Previous Pregnancies $(0-9+)$ 
KEY TO PUNCH CARD CODING (page 2)

(26) Previous abortions (0-9+)

(27) Children released for culoption $(0-9+)$

(28) Wants children sometime in the future. $0=$ not available, $1=$ yes, $2=$ no, $3=$ maybe

(29-37) Contraceptive knowledge and use. $0=$ not known or used, 1=known, but not used, $2=u s e d, 3=$ most frequent method during last two years, $4=$ not available, (No application form, Left blank on inadequately filled application form, and Not reported as used.)

(29) Rhythm or safe period

(30) Withdrawal or pulling out

(31) Pill

(32) Condom or rubber

(33) Foam, jelly or cream

(34) IUD (loop or coil)

(35) Diaphragm

(36) Douching

(37) Other

(38) Circumstances of pregnancy with regard to contraception 0=data not available, inadequate or contradictory, 1=attempting to get pregnant, $2=$ no attempt at contraception, $3=$ while using a reliable method, 4=while using an unreliable method. Reliable methods were: pills, IUD, Diaphragm, condoms, foam, vasectomy. Unreliable methods were: rhythm, withdrawal, douching

(39) Taken off pill or IUD by physician for medical reasons. 1=yes, $2=$ no, $0=$ no data, patient reports previous use of IUD or pills.

(40-41) Gestation (estimated week by calculation from last menstrual period or by examination) $00=$ not available. Examination has priority of authority over menstrual history.

(42) Too far along for abortion. 1=yes, 2=no ELIMINATED (appeared as factor in $(40-41)$

(43) Plan. 1=therapeutic abortion, 2=therapeutic abortion plus sterilization, 3 have child (has married or plans to marry) (These two 
KEY TO PUNCH CARD CODING (page 3)

groups were in fact separated in the final data analysis.) and keep child, 4=have child and keep (single woman), $5=$ released for adoption, $6=$ undecided, $7=h a v e$ baby, but undecided as to plan.

(44) Referral. $0=$ not available, 1=private physician, 2=medical school, $3=w e l$ fare, 4=other social agency, 5=no referral, 6=Emanual Hospital. (Kaiser was included under private physician and not separately tabulated).

(45) Confirmed outcome. $0=$ not known, 1=therapeutic abortion, $2=$ spontaneous abortion, $3=$ child born and kept, $4=$ child borm and released, $5=$ still borm

(46) Return for contraception. $0=$ no, 1=yes, 2=not due back, $3=$ returned after February 1. ( 3 not used-needed cut-off date for analyzing recorded data)

(47) Type of clinic. 1=regular contraceptive, 2=pregnancy counseling, $3=$ both

(48) Learned about clinic from 1=other patient (friend or relative,) $2=$ publicity, $3=$ school or social agency, $4=$ medical facility or physician, $5=0$ ther $\mathrm{PP}$ office, or $\mathrm{PP}$ personnel.

(49-51) Forms available, $0=$ not available, 1=available and adequate, $2=$ available but inadequate

(49) Contraceptive knowledge form

(50) Counseling form

(51) Medical history form 
Criteria for Adequacy: Unavailable Data

Gestation: This is self explanatory. The required minimum was either a recorded last menstrual period or an estimate by exam. Contraceptive circumstances: If the patient reported that they have ever used a method, or if there was no application form with a self report on use, the requirement was that the interviewer specifically state whether or not any form of contraception was being used. A few cases were also placed in this category because the client stated use of rhythm, withdrawal or douching only and the interviewer recorded no "birth control" a term which might indicate rejection of unreliable method data by the interviewer.

Plan: The record had to state the client's intention at the end of the interview or at last contact, but "undecided" was counted as a plan.

Referral: The requirement was a specific physician or agency or a specification "No referral".

The basic standard for adequacy of data was that anyone reviewing the record would not need to rely on guesswork even if probable. For instance, a record which stated that a patient had been referred to UOMS was classified as having a referral, but not a plan because while the probability would have been a therapeutic abortion, this would have also been appropriate for someone carrying the pregnancy. A case of an older woman which was probably a therapeutic abortion consultation from Kaiser was also classified as "Plan not available" because abortion was not mentioned in the record, which merely documented the fact of pregnancy and referred her to Kaiser where she was insured. 
Criteria for Adequacy: Forms

The Application for Pregnancy Counseling: The client was required to have provided an appropriate and consistent response but form was still considered adequate without income data or other dependents having an entry. It could not contradict information elsewhere, i.e. when nothing was recorded on "ever used" and the medical history indicated previous use of pills, the application was considered inadequate.

The Pregnancy Counseling Form: To be considered adequate, information had to be clear on contraception re conception, plan and referral. Gestation was only required if the last menstrual period was not reported on the application and there was no exam.

Medical History: The requirements were gestation and the nature of verification (Gravindex, UCG or exam). If no counseling form, additional requirements were last menstrual period, contraception re conception, plan and refercal.

\section{Data Transfer Sheet: Explanation}

After the preliminary sampling of 15 cases, information was coded directly from the record with one data sheet for each case. Individual comments and questions were recorded in the available space in the lower right hand comer. See Form IV.

\section{Key Punching:}

Since the data was precoded, the sheets could be sent directly for key punching. The original data transfer sheets were kept indexed by age and clinic number and the special notes were occasionally used for extra information. 
Clinic No.

Date

I apply for pregnancy testing which $I$ understand is completely confidential.

Signed :

Last Name First Name Maiden Name Husband

Address :

Street Apt.\# City $\quad$ Zip

Please fill in the following:

Date of Birth Age

When did your last menstrual period start?

Was it unusual in any way? Yes_ No___ Explain:

Give date of the menstrual period before the last one:

Highest Year of school completed: Are you a student now?

Are you working?

Yes No

Full Time

Part Time

Occasionally

Income: weekly (or) monthly Source of Income:

Do you live with your parents: Yes__ No

Number of your children living with you: Other dependents number

Please list below all of your pregnancies and outcome. List the name, sex and date of birth of each of your children, one on each line. Then list the approximate date of termination of your other pregnancies, and say whether the result was a child born dead, a miscarriage, an abortion or whatever. Use a separate line for each pregnancy. 
Clinic No.

Date

Have you done or used anything to keep from getting pregnant since your last menstrual period? Yes_ No N__

If So, what?

of the following methods of birth control, please check those which you know about and those which you have ever used:

METHOD HAVE HEARD OF ENOUGH TO USE HAVE USED

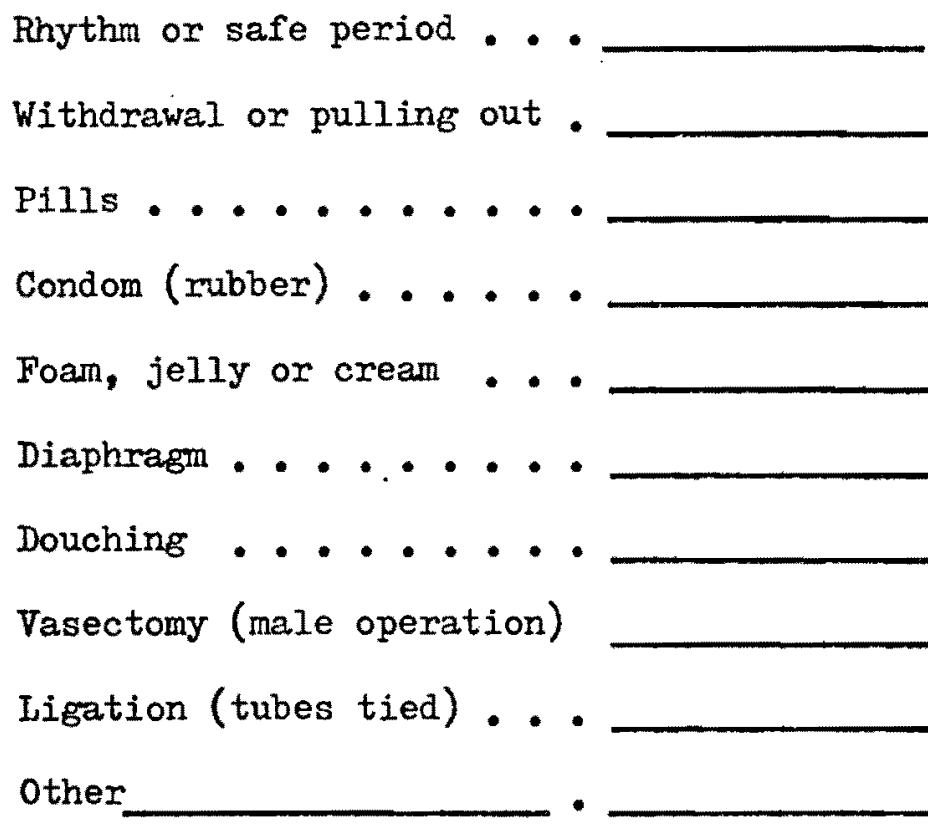

Have you ever had a birth control method prescribed for you by a doctor or a family planning clinic? Yes__ No If yes, what method? 
(Now in Use)

I apply for pregnancy testing and counseling which I understand is completely confidential.

Signed:

Last Name First Name Maiden Name Fnsband

Address :

Number Street Apt.\# City Zip Phone

Please fill in the following:

Date of Birth

Age?

How many years completed in school?

When did your last menstrual period start?

Please fill out the following form listing all pregnancies. Include any miscarriages or children born dead, or abortions

\begin{tabular}{ll}
\hline Boy Girl & Name \\
\hline 1. \\
\hline 2. \\
\hline 3. \\
4. \\
5. \\
\hline
\end{tabular}

Contraceptive History-of the following methods of birth control, check those which you know about and those you have ever used:

Know About

Rhythm or safe period

Withdrawal or pulling out

Pill

Condom, or rubber

Foam, jelly or cream

IUD (loop or coil)

Diaphragm

Douching

other
Ever Used

Rhythm or safe period

Withdrawal or pulling out

Pill

Condom, or rubber

Foam, jelly or cream

IUD (loop or coil)

Diaphragm

Douching

Other 
Date

Positive by: Gravindex

UCG

Interviewer

Exam

\section{PREGNANCY REPORT}

Patient No.

Birthdate

Patient Status: New Known only since last period old

Last Menstrual period:

Previous Menstrual Period

Purpose for which pregnancy test is being done:

Pregnancy counseling
Planned pregnancy
(No. of weeks of) Gestation estimated by:
Last menstrual period

Contraceptive Use Since Last Period:

A. No attempt at birth control.

B. Used:

Pills Brand Rx by phys, or clinic. Yes IUD Type In place Lost Not Known

Diaphragm

Condoms

Foam Rhythra Other \& Remarks Withdrawal Douching

C. Method reported as: Always used Sometimes used Used Wrong

Pregnancy Counseling: Yes No

PLAN: Have baby Therapeutic abortion

Abortion plus ligation Undecided

If undecided or to carry pregnancy: Due Date Referred to: Dr. Lovejoy Clinic Jofo Med. Sch. Enanuel Welfare other agency

\section{Attorney for emancipation:} No referral

Future birth control discussed: Yes No

Is patient expected to return for contraception? Yes No Should have follow-up. Yes. No When: 
FORM III

(Proposed)

REPORT OF FOLLOW-TP

Date

Patient Name:

Clinic No:

Counselor:
Contact:

By Telephone

In Office

Away from Agency

What Happened?

List Any new referral made:

Brief contact

Extended Interview

Would more time have been desirable? Yes No.

Further follow-up needed Yes

No

If yes, when? 
FORM IV

DATA TRANSFER SHEET

$$
\begin{aligned}
& \text { - - - - (1-6) Clinic \# } \\
& \text { _ (7-8) Mo prg test } \\
& \text { - (9) Patient status } \\
& \text { - (10) Marital status } \\
& \text { - (11) Color } \\
& \text { _ (12-13) Age in years } \\
& \text { - } \\
& \text { - - (16-17) Education (a) years com. } \\
& \text { - (18) Education (b) } \\
& \text { - (19) Education (c) } \\
& \text { _ (20) Income (type) } \\
& \text { _ (21) Support (source) } \\
& \text { - (22) Dependents (a) on income } \\
& \text { - (23) Dependents (b) children } \\
& \text { - (24) Live births 0-9+ } \\
& \text { - (25) Previous preg 0-9+ } \\
& \text { - (26) Prev, abortions 0-9+ } \\
& \text { _ (27) Ch. released 0-9+ } \\
& \text { - (28) Wants ch in fu } \\
& \text { _ (29) Rthm }
\end{aligned}
$$$$
\text { _.(30) Withdrawal }
$$$$
\text { - (31). P111 }
$$$$
\text { - (32) Condom }
$$$$
\text { - (33) Foam etc }
$$$$
\text { - (34) IUD }
$$$$
\text { - (35) Diaphragm }
$$$$
\text { - (36) Douching }
$$$$
\text { - (37) Other }
$$$$
\text { - (38) Circumstances }
$$$$
\text { - (39) Taken off } 1=\text { yes } 2=\text { no }
$$$$
\text { _ - (40-41) Gestation weeks }
$$$$
\text { - (42) Too far } 1=\text { yes } 2=\text { no }
$$$$
\text { _ (43) Plan }
$$$$
\text { _ (44) Referral }
$$$$
\text { - (45) Confirmed outcome }
$$$$
\text { - (46) Return for contracept }
$$$$
\text { _ (47) Type of clinic }
$$$$
\text { - (48) Leamed about clinic from }
$$$$
\text { - (49) Contraceptive kn. form }
$$$$
\text { _ (50) Counseling form }
$$$$
\text { _ (51) Medical History form }
$$ 
Figure 1

Age Distribution for

PCG and PCG Sample

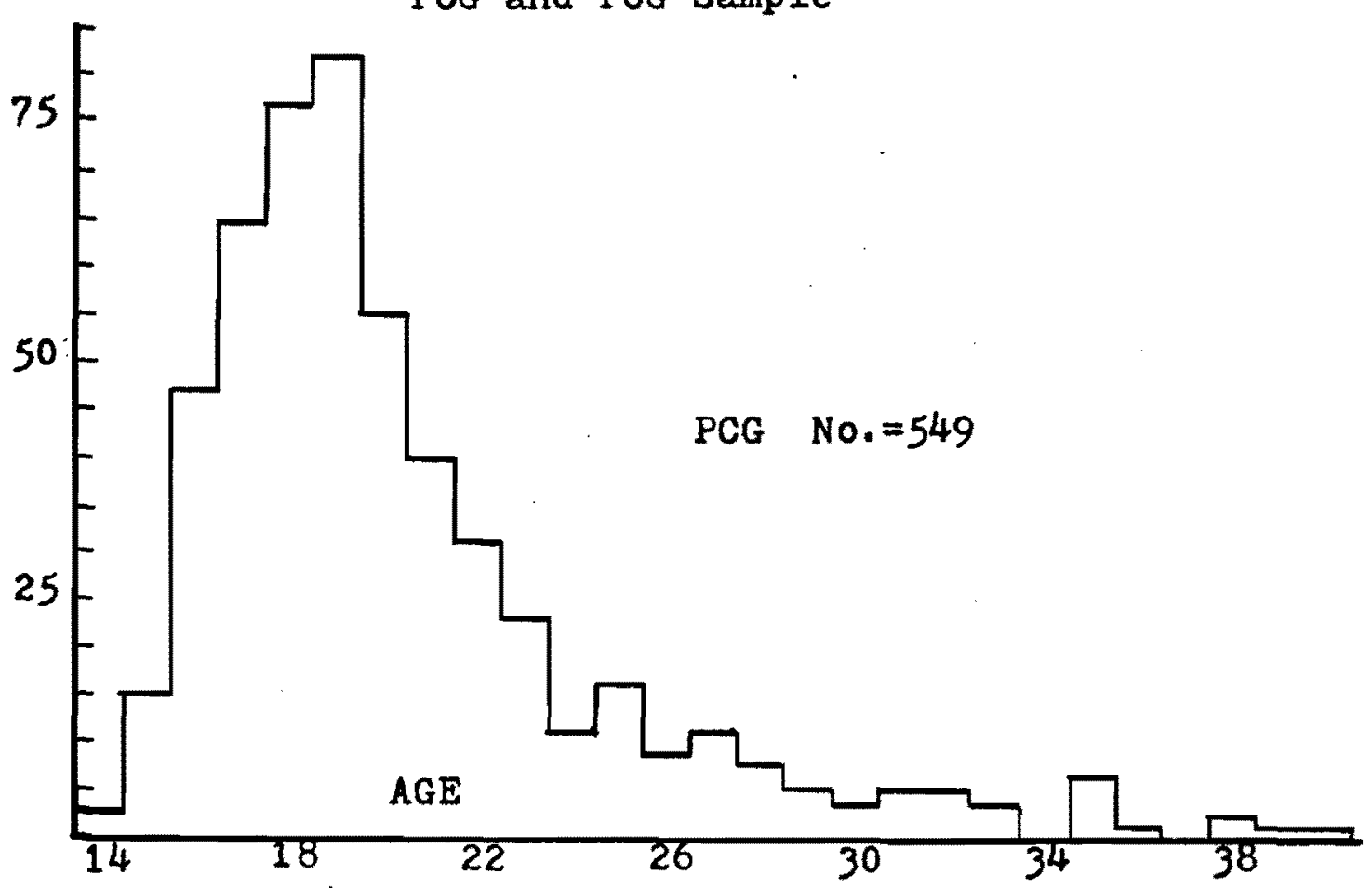

No.

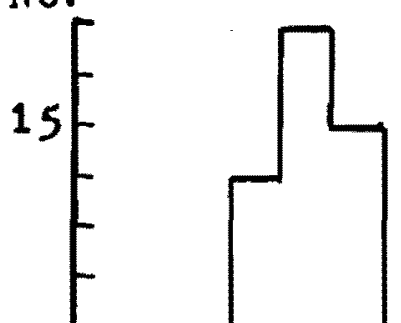

10

PCG Sample No. $=109$

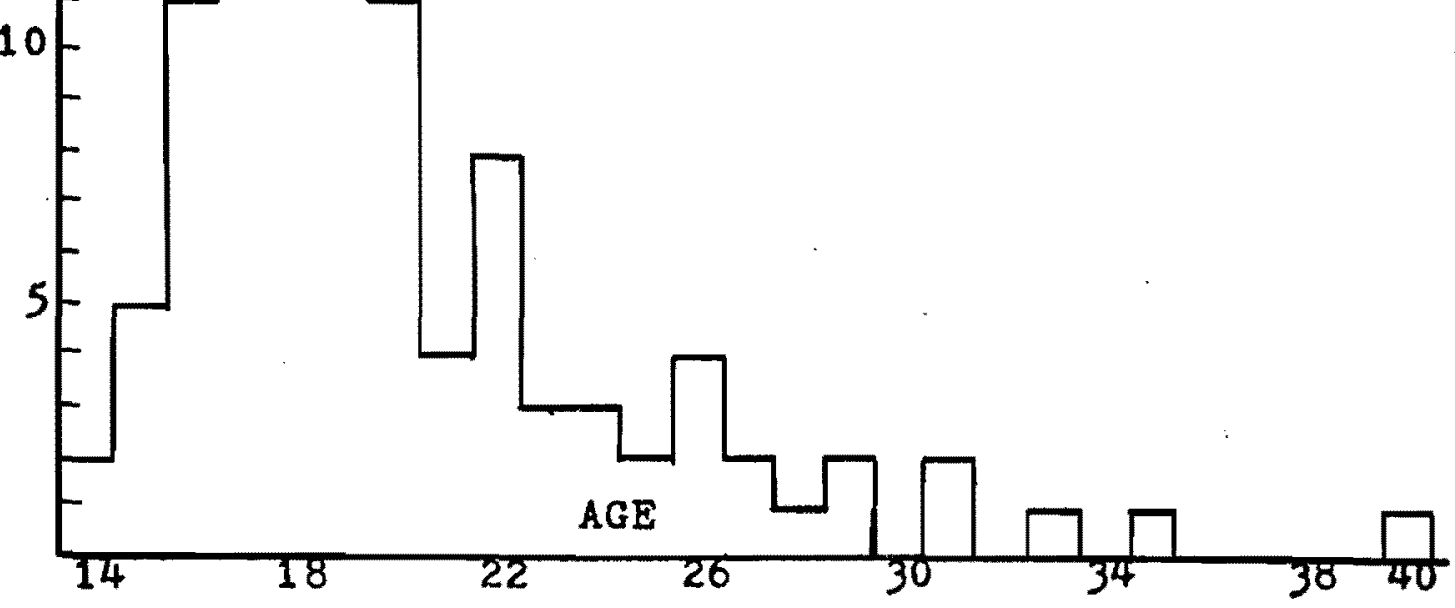



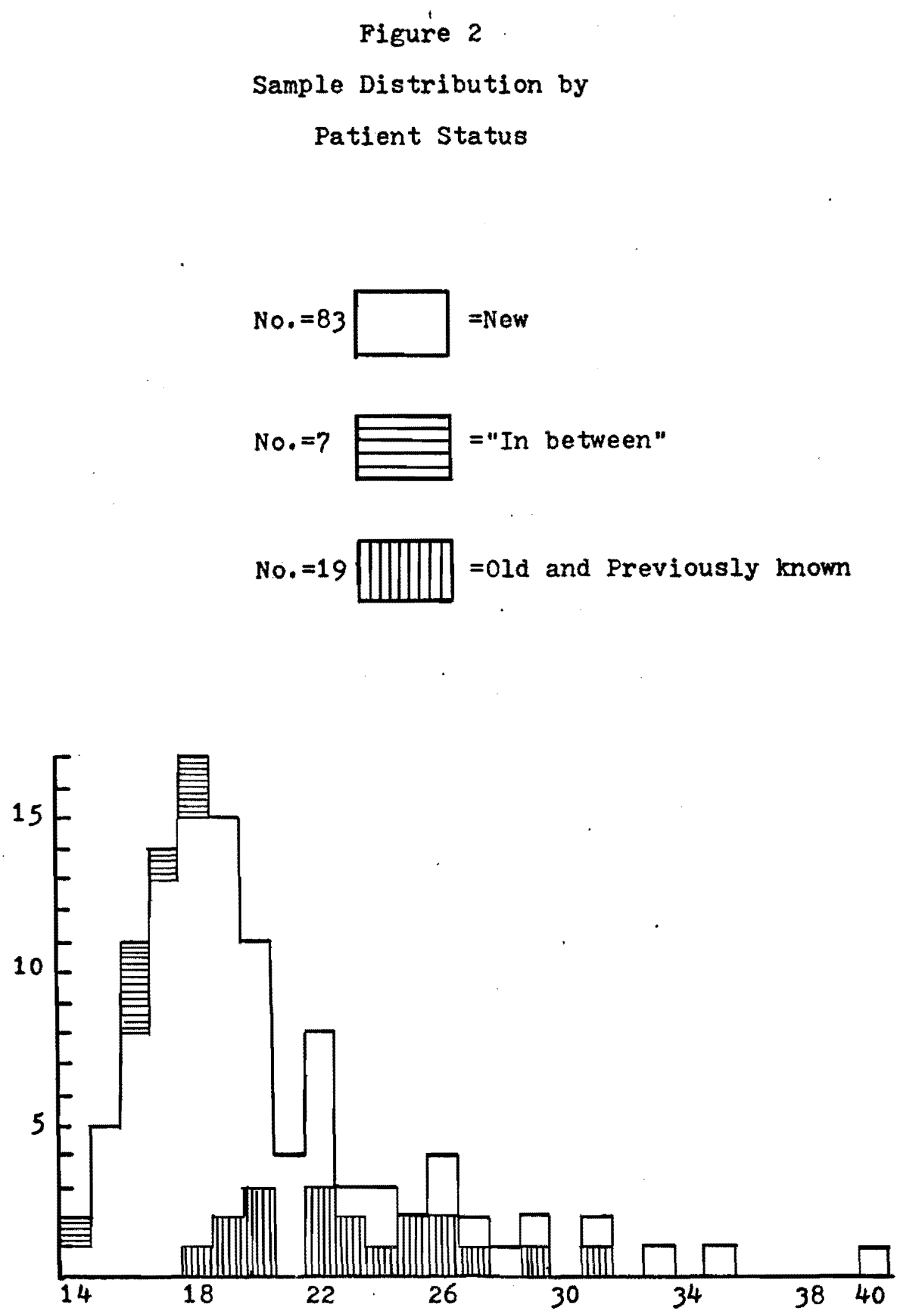
TABLE I

AGE DISTRIBUTIONS

TCP, Total Clinic Population PPA 1971

PCG, Pregnancy Counseling Group PPA 1971

(Sub-group of TCP, Mean=20.9, Median=19.9)

SAMPLE, $20 \%$ random sample of PCG

$($ Mean $=20.7$. Median=19.4)

\begin{tabular}{|c|c|c|c|c|c|c|}
\hline \multirow[b]{2}{*}{$A G E$} & \multicolumn{2}{|c|}{ TCP } & \multicolumn{2}{|c|}{ PCG } & \multicolumn{2}{|c|}{ SAMPLE } \\
\hline & No. & $\%$ & No. & $\%$ & No. & $\%$ \\
\hline UNDER 15 & 27 & .4 & 3 & .5 & 2 & 1.8 \\
\hline 15 to 19 & 2499 & 38.5 & 301 & 54.8 & 61 & 55 \\
\hline 20 to 24 & 2977 & 45.9 & 162 & 29.5 & 30 & 27.6 \\
\hline 25 to 29 & 686 & 10.6 & 55 & 10.0 & 11 & 10.1 \\
\hline 30 to 34 & 180 & 2.8 & 17 & 3.1 & 3 & 2.7 \\
\hline 35 to 39 & 70 & 1.1 & 10 & 1.8 & 1 & .9 \\
\hline 40 to 44 & 30 & .5 & 1 & .2 & 1 & .9 \\
\hline OVER 45 & 22 & .3 & 0 & 0 & 0 & 0 \\
\hline & 6491 & TOTAL & 549 & TOTAL & 109 & OTAL \\
\hline
\end{tabular}


TABLE II

EDUCATION BY AGE I

\begin{tabular}{|c|c|c|c|c|c|c|c|c|c|c|c|}
\hline \multirow[b]{2}{*}{ AGE } & \multicolumn{10}{|c|}{ YEARS OF SCHOOL COMPLETED } & \multirow[b]{2}{*}{ TOTAL } \\
\hline & 7 & 8 & 9 & 10 & 11 & 12 & 13 & 14 & 15 & $16+$ & \\
\hline 14 & & 1 & 1 & & & & & & & & 2 \\
\hline 15 & & & 3 & 2 & & & & & & & 5 \\
\hline 16 & & & & 11 & & & & & & & 11 \\
\hline 17 & & 1 & & 3 & 9 & & & & & & 13 \\
\hline 18 & & & & & 3 & 14 & & & & & 17 \\
\hline 19 & & & & 1 & 1 & 10 & 3 & & & & 15 \\
\hline 20 & & & & & & 7 & 2 & 2 & & & 11 \\
\hline 21 & & & & & & 2 & 1 & & & 1 & 4 \\
\hline 22 & & & & & & 4 & 1 & 2 & 1 & 1 & 9 \\
\hline 23 & & & & & 1 & & & 1 & 1 & & 3 \\
\hline 24 & & & & & & 3 & & & & & 3 \\
\hline $25+$ & 1 & & & & 1 & 6 & 3 & & & 5 & 16 \\
\hline TOTAL: & 1 & 2 & 4 & 17 & 15 & 46 & 10 & 5 & 2 & 7 & 109 \\
\hline
\end{tabular}


TABLE III

EDUCATION BY AGE II

TCP AND SAMPLE OF PCG

\begin{tabular}{|c|c|c|c|c|c|c|c|c|}
\hline \multirow[b]{3}{*}{ AGE: } & \multicolumn{8}{|c|}{ YEARS SCHOOI CONPLETED } \\
\hline & \multicolumn{2}{|c|}{7 or 8} & \multicolumn{2}{|c|}{9 to 11} & \multicolumn{2}{|c|}{12} & \multicolumn{2}{|c|}{ over 12} \\
\hline & TCP & PCG & TCP & PCG & TCP & PCG & $\mathrm{TCP}$ & PCG \\
\hline under & 18 & 1 & 7 & 1 & 1 & 0 & 1 & 0 \\
\hline 15 & $\cdot 3 \%$ & $.9 \%$ & $.1 \%$ & $.9 \%$ & - & - & - & - \\
\hline 15 & 30 & 1 & 1310 & 33 & 916 & 24 & 230 & 3 \\
\hline 19 & $.5 \%$ & $.9 \%$ & $20.2 \%$ & $30.3 \%$ & $14.1 \%$ & $22.1 \%$ & $3.5 \%$ & $2.8 \%$ \\
\hline 20 & 6 & 0 & 214 & 1 & 1087 & 16 & 1654 & 13 \\
\hline 24 & $.1 \%$ & - & $3 \cdot 3 \%$ & $.9 \%$ & $16.8 \%$ & $14.7 \%$ & $25.5 \%$ & $12 \%$ \\
\hline 25 & 11 & 1 & 61 & 1 & 231 & 4 & 371 & 5 \\
\hline 29 & $.2 \%$ & $.9 \%$ & $1 \%$ & $.9 \%$ & $3.5 \%$ & $3.7 \%$ & $5.8 \%$ & $4.8 \%$ \\
\hline 30 & 2 & 0 & 30 & 0 & 69 & 1 & 70 & 2 \\
\hline 34 & - & - & $.5 \%$ & - & $1.1 \%$ & $.9 \%$ & $1.1 \%$ & $1.8 \%$ \\
\hline 35 & 4 & 0 & 16 & 0 & 27 & 1 & 15 & 0 \\
\hline 39 & $.1 \%$ & - & $.3 \%$ & - & $.4 \%$ & $.9 \%$ & $.3 \%$ & - \\
\hline over & 3 & 0 & 10 & 0 & 22 & 0 & 17 & 0 \\
\hline 40 & - & - & $.2 \%$ & - & $\cdot 3 \%$ & - & $.3 \%$ & - \\
\hline
\end{tabular}


TABLE IV

DECISION BY RACE

* woman with planned pregnancy, single

* *married woman with planned pregnancy

\begin{tabular}{|c|c|c|c|c|}
\hline DECISION & $\begin{array}{l}\text { TOTAL } \\
\text { GROUP }\end{array}$ & WHITE & BLACK & OTHER \\
\hline \multirow{2}{*}{$\begin{array}{l}\text { THERAPEUTIC } \\
\text { ABORTION }\end{array}$} & 66 & 57 & 7 & 2 \\
\hline & $60.6 \%$ & $60.4 \%$ & $58.3 \%$ & $66.7 \%$ \\
\hline \multirow{2}{*}{$\begin{array}{l}\text { MARRIAGE } \\
\text { AND BABY }\end{array}$} & 17 & 13 & 3 & $1^{*}$ \\
\hline & $15.6 \%$ & $13.8 \%$ & $25 \%$ & $33.3 \%$ \\
\hline \multirow{2}{*}{$\begin{array}{l}\text { SINGLE } \\
\text { AND BABY }\end{array}$} & 6 & $5 *$ & 1 & - \\
\hline & $5.5 \%$ & $5.3 \%$ & $8.3 \%$ & - \\
\hline \multirow{2}{*}{$\begin{array}{l}\text { HAVE BABY AND } \\
\text { DECIDE LATER }\end{array}$} & 3 & 3 & - & - \\
\hline & $2.8 \%$ & $3.2 \%$ & - & - \\
\hline \multirow{2}{*}{ UNDECIDED } & 7 & 7 & - & - \\
\hline & $6.4 \%$ & $7.4 \%$ & - & - \\
\hline \multirow{2}{*}{ UNAVAILABLE } & 10 & 9 & 1 & - \\
\hline & $9.2 \%$ & $9.5 \%$ & $8.3 \%$ & - \\
\hline \multirow[t]{2}{*}{ TOTAL } & 109 & 94 & 12 & 3 \\
\hline & $100 \%$ & & & \\
\hline
\end{tabular}


TABLE V

SOURCE OF SUPPORT AND

LIVING SITUATION

\begin{tabular}{|c|c|c|c|c|c|c|}
\hline $\begin{array}{c}\text { *Type of living } \\
\text { situation }\end{array}$ & \multicolumn{2}{|c|}{$\begin{array}{l}\text { TOTAL } \\
14 \text { to } 40\end{array}$} & \multicolumn{2}{|c|}{14 to 18} & \multicolumn{2}{|c|}{19 to 40} \\
\hline $\begin{array}{l}\text { *Type of } \\
\text { support }\end{array}$ & No. & $\%$ & No. & $\%$ & No. & $\%$ \\
\hline $\begin{array}{l}\text { Parents and } \\
\text { Relatives }\end{array}$ & 32 & $34.4 \%$ & 27 & $68.4 \%$ & 5 & $9.5 \%$ \\
\hline $\begin{array}{l}\text { Welfare } \\
\text { Child }\end{array}$ & 3 & $3.2 \%$ & 3 & $.2 \%$ & - & - \\
\hline 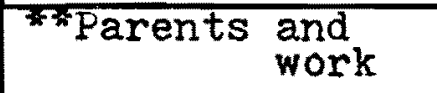 & 3 & $3.2 \%$ & 2 & $4.8 \%$ & 1 & $1.9 \%$ \\
\hline $\begin{array}{c}\text { Total family of } \\
\text { Origin }\end{array}$ & 38 & $40.9 \%$ & 32 & $78.8 \%$ & 6 & $11.4 \%$ \\
\hline "Supported by & 12 & $12.9 \%$ & 1 & $2.4 \%$ & 11 & $20.9 \%$ \\
\hline $\begin{array}{l}\text { * Supported by } \\
\text { husb.\& own work }\end{array}$ & 2 & $2.2 \%$ & - & - & 2 & $3.8 \%$ \\
\hline $\begin{array}{l}\text { Welfare } \\
\text { Adult }\end{array}$ & 7 & $7 \cdot 7 \%$ & 2 & $.8 \%$ & 5 & $9.5 \%$ \\
\hline $\begin{array}{l}\text { Total family of } \\
\text { Emancipation }\end{array}$ & 21 & $22.9 \%$ & 3 & $7.2 \%$ & 18 & $34.2 \%$ \\
\hline $\begin{array}{l}\text { * Supported by } \\
\text { own earn. only }\end{array}$ & * 34 & $35.5 \%$ & 6 & 14 & 28 & $53.8 \%$ \\
\hline $\begin{array}{c}\text { Totals in Eroups } \\
\text { by age }\end{array}$ & 93 & $\begin{array}{l}\operatorname{tal} \\
040\end{array}$ & $\begin{array}{l}\text { I1 } \\
14\end{array}$ & tal 18 & 52 & $\begin{array}{l}\text { tal } \\
\text { to } 40\end{array}$ \\
\hline
\end{tabular}

**12 or $12.9 \%$ have dependents also supported by this income. 
TABLE VI

REPRODUCTIVE HISTORY

\begin{tabular}{|c|c|c|c|c|c|c|c|}
\hline \multirow{2}{*}{\multicolumn{2}{|c|}{$\begin{array}{c}\text { Pregnancy and } \\
\text { Outcome }\end{array}$}} & \multicolumn{2}{|c|}{$\begin{array}{l}109 \text { TOTAL } \\
14 \text { to } 40\end{array}$} & \multicolumn{2}{|c|}{14 to 18} & \multicolumn{2}{|c|}{19 to 40} \\
\hline & & No. & $\%$ & No. & $\%$ & No. & $\%$ \\
\hline \multicolumn{2}{|c|}{$\begin{array}{c}\text { Previous Pregnancies } \\
\text { NONE }\end{array}$} & 72 & 66.1 & 42 & 87.0 & 30 & 49.2 \\
\hline \multicolumn{2}{|c|}{ ONE } & 24 & 22.0 & 5 & 10.5 & 19 & 31.1 \\
\hline \multicolumn{2}{|c|}{ TWO } & 4 & 3.6 & 1 & 2.1 & 3 & 4.9 \\
\hline \multicolumn{2}{|c|}{ THREE } & 7 & 6.4 & - & - & 7 & 11.5 \\
\hline \multicolumn{2}{|c|}{ FOUR } & 2 & 1.8 & - & - & 2 & $3 \cdot 3$ \\
\hline \multicolumn{2}{|c|}{ Previous Abortions } & 6 & 5.5. & 2 & 4.1 & 4 & 6.5 \\
\hline $\begin{array}{l}\text { Live Births } \\
\text { NONE }\end{array}$ & $\begin{array}{l}\text { TCP\% } \\
73.3\end{array}$ & 83 & .75 .7 & 46 & 95.8 & 37 & 60.8 \\
\hline ONE & $15 \cdot 3$ & 13 & 11.1 & 1 & 2.1 & 12 & 19.6 \\
\hline TWO & 6.2 & 6 & 5.5 & 1 & 2.1 & 5 & 8.2 \\
\hline THREE & $\begin{array}{l}3+ \\
5.1\end{array}$ & 5 & 4.6 & - & - & 5 & 8.2 \\
\hline \multicolumn{2}{|l|}{ FOUR } & 2 & 1.8 & - & - & 2 & $3 \cdot 3$ \\
\hline \multicolumn{2}{|c|}{$\begin{array}{l}\text { Children Released } \\
6 \text { children } 5 \text { mothers }\end{array}$} & ${ }^{*}$ & 4.6 & 1 & 2.1 & $*$ & 6.5 \\
\hline \multicolumn{2}{|c|}{$\begin{array}{c}\text { Children with mother } \\
\text { NONE }\end{array}$} & 85 & 78.0 & 46 & 95.8 & 39 & 63.9 \\
\hline \multicolumn{2}{|c|}{ ONE } & 11 & 10.1 & 2 & 4.2 & 9 & 14.7 \\
\hline \multicolumn{2}{|c|}{ TWO } & 6 & 5.2 & - & - & ${ }^{*} 6$ & 9.9 \\
\hline \multicolumn{2}{|c|}{ THREE } & 5 & 4.6 & - & - & 5 & 8.2 \\
\hline \multicolumn{2}{|c|}{ FOUR } & ** 2 & 1.8 & - & - & ${ }^{* *} 2$ & 3.3 \\
\hline
\end{tabular}

*1 mo. released $2 \mathrm{ch}$. \& kept 2 . *1 mo. has 3 adopt.ch. 


\section{TABLE VII}

HOW THEY CAME

TO THE AGENCY

\begin{tabular}{|c|c|c|c|c|}
\hline $\begin{array}{l}\text { HOW THEY CAME } \\
\text { TO THE AGENCY }\end{array}$ & $\begin{array}{c}\text { PCG } \\
109 \\
14--40\end{array}$ & $\begin{array}{c}\text { PCG } \\
48 \\
14--18\end{array}$ & $\begin{array}{c}\text { PCG } \\
61 \\
19--40\end{array}$ & TCP \\
\hline \multirow{2}{*}{$\begin{array}{l}\text { OTHER PATIENT } \\
\text { FRIEND OR RELATIVE }\end{array}$} & 78 & 39 & 39 & \\
\hline & $71.7 \%$ & $81 \%$ & $64 \%$ & $62.8 \%$ \\
\hline \multirow{2}{*}{$\begin{array}{l}\text { SELF AND } \\
\text { PUBLICITY }\end{array}$} & 10 & 3 & 7 & \\
\hline & $9.2 \%$ & $6.3 \%$ & $11.5 \%$ & $13.6 \%$ \\
\hline \multirow{2}{*}{$\begin{array}{l}\text { SCHOOL OR } \\
\text { SOCIAL AGENCY }\end{array}$} & 8 & 4 & 4 & \\
\hline & $7 \cdot 3 \%$ & $8.4 \%$ & $6.6 \%$ & $7.7 \%$ \\
\hline \multirow{2}{*}{$\begin{array}{l}\text { PHYSICIAN OR } \\
\text { MEDICAL AGENCY }\end{array}$} & 11 & 2 & 9 & \\
\hline & $10.1 \%$ & $4.2 \%$ & $14.7 \%$ & $8.7 \%$ \\
\hline \multirow{2}{*}{$\begin{array}{c}\text { PPA } \\
\text { PERSONNEL }\end{array}$} & 2 & - & 2 & \\
\hline & $1.8 \%$ & - & $3.3 \%$ & $6.1 \%$ \\
\hline
\end{tabular}


TABLE VIII

PATIENT STATUS

\begin{tabular}{|c|c|c|c|c|c|c|}
\hline \multirow{2}{*}{ STATUS } & \multicolumn{2}{|c|}{14 to 40} & \multicolumn{2}{|c|}{14 to 18} & \multicolumn{2}{c|}{19 to 40} \\
\cline { 2 - 7 } & No. & $\%$ & No. & $\%$ & No. & $\%$ \\
\hline New & 83 & 77.1 & 40 & 36.7 & 43 & 39.5 \\
\hline "In Between" & 7 & 6.4 & 7 & 6.4 & - & - \\
\hline Previously known & 3 & 2.8 & - & - & 3 & 2.8 \\
\hline Old Patients & 16 & 14.7 & 1 & .9 & 15 & 13.8 \\
\hline Totals & 109 & $100 \%$ & 48 & $44 \%$ & 61 & $56 \%$ \\
\hline
\end{tabular}

STATUS

New

"In Betweens"

Previously know

old Patients

Total Sample
AGE RANGE

14 to 40

14 to 18

20 to 29

18 to 31

14 to 40
MEAN AGE

19.2

16.9

24.0

23.6

20.7 
TABLE IXA

$N R=$ Number

CONTRACEPTIVE KNOWLEDGE AND USE

Responding

$P R=$ Positive

Response

\begin{tabular}{|c|c|c|c|c|c|c|c|c|c|}
\hline Response & NR & PR & $\frac{\mathrm{PR}}{\mathrm{NR}}$ & NR & PR & $\frac{P R}{N R}$ & NR & PR & $\frac{\mathrm{PR}}{\mathrm{NR}}$ \\
\hline \multirow{2}{*}{$\begin{array}{l}\text { know about } \\
\text { RHYTHM } \\
\text { have used }\end{array}$} & 25 & 15 & .60 & 11 & 6 & .55 & 55 & 43 & .80 \\
\hline & 25 & 10 & .40 & 11 & 5 & .46 & 55 & 23 & .42 \\
\hline \multirow{2}{*}{$\begin{array}{l}\text { know about } \\
\text { WITHDRAWAL } \\
\text { have used }\end{array}$} & 25 & 16 & .64 & 12 & 8 & .67 & 54 & 44 & .82 \\
\hline & 25 & 8 & .32 & 12 & 5 & .42 & 54 & 29 & .54 \\
\hline \multirow{2}{*}{$\begin{array}{l}\text { know about } \\
\text { PIILS } \\
\text { have used }\end{array}$} & 25 & 18 & .72 & 13 & 12 & .92 & 59 & 58 & .98 \\
\hline & 25 & 2 & .08 & 13 & 4 & .31 & 59 & 32 & .54 \\
\hline \multirow{2}{*}{$\begin{array}{l}\text { know about } \\
\text { CONDOMS } \\
\text { have used }\end{array}$} & 25 & 20 & .80 & 13 & 10 & .77 & 54 & 45 & .83 \\
\hline & 25 & 9 & $\cdot 36$ & 13 & 3 & .22 & 54 & 23 & .43 \\
\hline \multirow{2}{*}{$\begin{array}{l}\text { know about } \\
\text { FOAM ETC. } \\
\text { have used }\end{array}$} & 25 & 12 & .48 & 12 & 9 & .75 & 55 & 47 & .86 \\
\hline & 25 & 5 & .20 & 12 & 2 & .17 & 55 & 26 & .47 \\
\hline \multirow{2}{*}{$\begin{array}{l}\text { know about } \\
\text { have used }\end{array}$} & 25 & 8 & $\cdot 32$ & 12 & 5 & .42 & 56 & 48 & .86 \\
\hline & 25 & 0 & - & 11 & 0 & -- & 56 & 10 & .18 \\
\hline \multirow{2}{*}{$\begin{array}{l}\text { know about } \\
\text { DIAPHRAGM } \\
\text { have used }\end{array}$} & 25 & 12 & .48 & 12 & 5 & .42 & 53 & 39 & .73 \\
\hline & 25 & 0 & -- & 11 & 0 & -- & 53 & 4 & .08 \\
\hline \multirow{2}{*}{$\begin{array}{l}\text { know about } \\
\text { DOUCHING } \\
\text { have used }\end{array}$} & 25 & 13 & .44 & 12 & 6 & .50 & 53 & 36 & .68 \\
\hline & 25 & 4 & .16 & 12 & 1 & .08 & 53 & 11 & .21 \\
\hline \multirow{2}{*}{$\begin{array}{l}\text { 9THER } \\
\text { masectoiny onl } \\
\text { method reported }\end{array}$} & -- & $-\infty$ & $\cdots$ & -- & -- & --- & 53 & 4 & .07 \\
\hline & - & - & --- & - & -- & -- & 53 & 3 & .05 \\
\hline
\end{tabular}


TABLE IXB

\begin{tabular}{|c|c|c|c|c|c|c|c|c|c|}
\hline \multirow{3}{*}{$\begin{array}{l}N R=\text { Number } \\
\text { Responding } \\
\text { PR=Positive } \\
\text { Response }\end{array}$} & \multicolumn{9}{|c|}{ KNOW.\& USE YOUNGER PTS. } \\
\hline & \multicolumn{3}{|c|}{${ }^{*} 14-17(26)$} & \multicolumn{3}{|c|}{ * $18(15)$} & \multicolumn{3}{|c|}{$19(15)$} \\
\hline & NR & PR & $\frac{P R}{N R}$ & $\mathrm{NR}$ & PR & $\frac{P R}{N R}$ & NR & PR & $\frac{P R}{N R}$ \\
\hline \multirow{2}{*}{$\begin{array}{l}\text { know about } \\
\text { RHYTHM } \\
\text { have used }\end{array}$} & 19 & 11 & .58 & 10 & 5 & .50 & 14 & 12 & .86 \\
\hline & 19 & 9 & .47 & 10 & 5 & .50 & 14 & 5 & $\cdot 36$ \\
\hline \multirow{2}{*}{$\begin{array}{l}\text { know about } \\
\text { WITHDRAWAI } \\
\text { have used }\end{array}$} & 19 & 12 & .63 & 11 & 7 & .64 & 14 & 12 & .86 \\
\hline & 19 & 6 & $\cdot 32$ & 11 & 5 & .45 & 14 & 7 & .50 \\
\hline \multirow{2}{*}{$\begin{array}{l}\text { know about } \\
\text { PIIIS } \\
\text { have used }\end{array}$} & 19 & 13 & .68 & 11 & 10 & .91 & 15 & 15 & 1.0 \\
\hline & 19 & 1 & .05 & 11 & 3 & .27 & 15 & 7 & .46 \\
\hline \multirow{2}{*}{$\begin{array}{l}\text { know about } \\
\text { CoNDoms } \\
\text { have used }\end{array}$} & 19 & 15 & .79 & 12 & 9 & .75 & 14 & 14 & 1.0 \\
\hline & 19 & 5 & .26 & 12 & 3 & .25 & 14 & 5 & $\cdot 36$ \\
\hline \multirow{2}{*}{$\begin{array}{l}\text { know about } \\
\text { FOAM ETC. } \\
\text { have used }\end{array}$} & 19 & 7 & $\cdot 37$ & 11 & 8 & .73 & 14 & 12 & .86 \\
\hline & 19 & 2 & .11 & 11 & 2 & .18 & 14 & 6 & .43 \\
\hline \multirow{2}{*}{$\begin{array}{l}\text { know about } \\
\text { IUD } \\
\text { have used }\end{array}$} & 19 & 4 & .21 & 11 & 4 & .36 & 14 & 11 & .79 \\
\hline & 19 & 0 & -- & 11 & 0 & -- & 14 & 1 & .07 \\
\hline \multirow{2}{*}{$\begin{array}{l}\text { know about } \\
\text { DIAPHRAGM } \\
\text { have used }\end{array}$} & 19 & 7 & $\cdot 37$ & 11 & 5 & .46 & 14 & 12 & .86 \\
\hline & 19 & 0 & -- & 11 & 0 & $-\infty$ & 14 & 0 & -- \\
\hline \multirow{2}{*}{$\begin{array}{l}\text { know about } \\
\text { DouchING } \\
\text { have used }\end{array}$} & 19 & 11 & .58 & 11 & 5 & .46 & 14 & 11 & .79 \\
\hline & 19 & 4 & .21 & 12 & 1 & .08 & 14 & 2 & .16 \\
\hline
\end{tabular}

* Sample reduced for the $14-17$ and 18 year old by removing the "In between" group that had contraceptive class on initial clinic visit. 
TABLE IXC

CONTRACEPTION AT TIME OF CONCEPTION

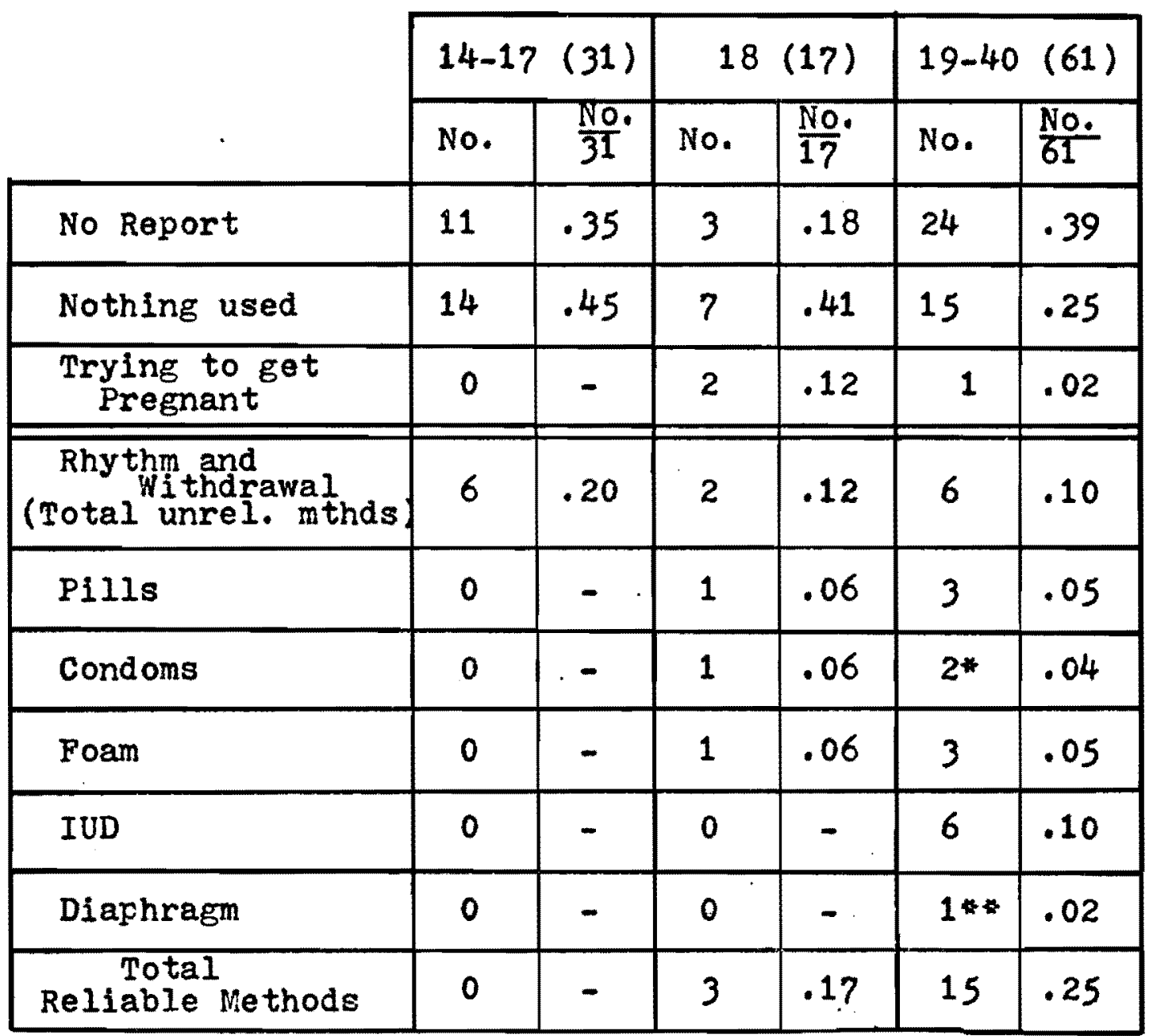

* One reported using condoms and foam, (not reported under Foam.)

* Reported as also relying on husband's vasectomy. 
TABLE X

HISTORY OF PILL AND IUD USE

\begin{tabular}{|c|c|c|c|c|}
\hline & $\begin{array}{l}\text { To } \\
14 \\
\text { No. }\end{array}$ & $\begin{array}{cc}\text { tal } & 4 ? \\
\text { to } & 40 \\
& \%\end{array}$ & $\begin{array}{l}14 \overline{8} \\
18 \\
\text { No. }\end{array}$ & $\begin{array}{l}19- \\
40 \\
\text { No. }\end{array}$ \\
\hline Kethod failure & 10 & $21 \cdot 3$ & 1 & 9 \\
\hline $\begin{array}{l}\text { Discontinued on } \\
\text { Medical Advice }\end{array}$ & 8 & 17.0 & 1 & 7 \\
\hline $\begin{array}{c}\text { Discontinued } \\
\text { on own }\end{array}$ & 12 & 25.2 & 1 & 11 \\
\hline $\begin{array}{l}\text { No information } \\
\text { re: Discontinued }\end{array}$ & 17 & 36.2 & 3 & 14 \\
\hline Totals & 47 & 100 & 6 & 41 \\
\hline
\end{tabular}

TABLE XI

STATUS BY CONTRACEPTIVE CIRCUMSTANCE

\begin{tabular}{|c|c|c|c|c|c|c|c|}
\hline & $\begin{array}{l}\text { New } \\
\text { Pt. }\end{array}$ & $\begin{array}{l}\text { Old } \\
\text { Pt. }\end{array}$ & $\operatorname{In}_{\text {Betw. }}$ & $\begin{array}{l}\text { Prev } \\
\text { Known }\end{array}$ & $\begin{array}{l}\text { Newt } \\
\text { In } \\
\text { Betw. }\end{array}$ & \multicolumn{2}{|c|}{$\begin{array}{l}\text { Total } \\
\text { No. } \%\end{array}$} \\
\hline Not Known & 31 & 3 & 3 & 1 & 33 & 38 & 35.4 \\
\hline $\begin{array}{l}\text { Trying to get } \\
\text { Pregnant }\end{array}$ & 3 & 0 & 0 & 0 & 3 & 3 & 2.8 \\
\hline Using $_{\text {Nothing }}$ & 26 & 5 & 4 & 1 & 30 & 36 & 34.0 \\
\hline $\begin{array}{l}\text { Reliable } \\
\text { Method }\end{array}$ & 7 & 8 & 0 & 1 & 7 & 16 & 14.7 \\
\hline $\begin{array}{l}\text { Unreliable } \\
\text { Wethod }\end{array}$ & 14 & 0 & 0 & 0 & 14 & 14 & 12.8 \\
\hline
\end{tabular}


TABLE XII

GESTATION BY AGE

Sample reduced by $8(N=101)$

\begin{tabular}{|c|c|c|c|c|c|c|c|}
\hline \multirow{2}{*}{$\begin{array}{l}\text { Weeks of } \\
\text { Gestation }\end{array}$} & \multicolumn{2}{|c|}{14 to 18} & \multicolumn{2}{|c|}{$19-20$} & \multicolumn{2}{|c|}{21 to 40} & \\
\hline & No. & $\frac{\text { No. }}{47}$ & No. & $\frac{\text { No. }}{24}$ & No. & $\frac{\text { No. }}{30}$ & \\
\hline 5 to 9 & 20 & .43 & 19 & .79 & 24 & .80 & Best D\&C \\
\hline $10-11$ & 17 & .36 & 1 & .04 & 5 & .17 & Still D\&C \\
\hline 12 & 3 & .06 & - & -- & - & -- & Borderline \\
\hline $13-21$ & 5 & .11 & 4 & .17 & $1 *$ & .03 & Saline \\
\hline $21+$ & 2 & .04 & - & - & - & - & Too Late \\
\hline Total No. & 47 & $47 \%$ & 24 & $24 \%$ & 30 & $30 \%$ & $\begin{array}{l}\text { Percentage of } \\
\text { Sample }\end{array}$ \\
\hline
\end{tabular}

TABLE XIII

GESTATION BY RELIABLE METHOD FAILURE

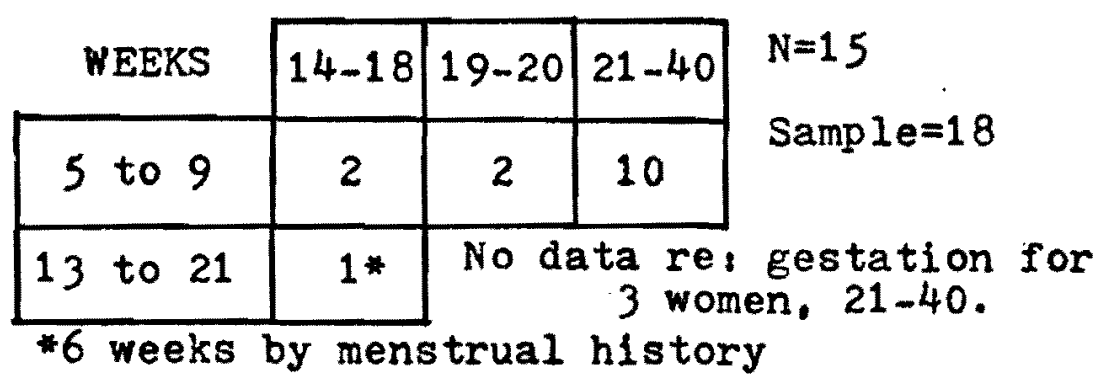


TABLE XIV

"IN BETWEEN"GROUP BY GESTATION

\begin{tabular}{|c|c|c|c|c|c|c|c|}
\hline \multirow{2}{*}{$\begin{array}{l}\text { Weeks of } \\
\text { Gestation }\end{array}$} & \multicolumn{2}{|c|}{$\begin{array}{c}\text { Total } \\
14-18\end{array}$} & \multicolumn{2}{|c|}{$\begin{array}{c}\text { Other } \\
14-18\end{array}$} & \multicolumn{2}{|c|}{$\begin{array}{c}\text { "In } \\
\text { Betweens" }\end{array}$} & \multirow[b]{3}{*}{ Best D\&C } \\
\hline & No. & $\frac{\text { No. }}{48}$ & No. & $\frac{\text { No. }}{41}$ & No. & $\frac{\text { No. }}{7}$ & \\
\hline $5-9$ & 20 & .42 & 20 & .49 & 0 & - & \\
\hline $10-11$ & 17 & $\cdot 36$ & 14 & .33 & 3 & .43 & Still D\&C \\
\hline 12 & 3 & .06 & 2 & .05 & 1 & .14 & Borderline \\
\hline $13-21$ & 5 & .11 & 2 & .05 & 3 & .43 & Saline \\
\hline $21+$ & 2 & .04 & 2 & .05 & 0 & - & Too Late \\
\hline $\begin{array}{l}\text { Not } \\
\text { Available }\end{array}$ & 1 & .02 & 1 & .02 & - & - & \\
\hline Totals & 48 & & 41 & & $?$ & & \\
\hline
\end{tabular}

Note, The "In Between" group account for $29 \%$ of the probable saline abortions in the total sample of 109 .

TABLE XV

"IN BETHEEN"GROUP BY DECISION

\begin{tabular}{|c|c|c|c|c|c|c|}
\hline \multirow{2}{*}{ Decision } & \multicolumn{2}{|c|}{$\begin{array}{c}\text { Total } \\
14-18\end{array}$} & \multicolumn{2}{|c|}{$\begin{array}{l}\text { Other } \\
14-18\end{array}$} & \multicolumn{2}{|c|}{$\begin{array}{l}\text { "In } \\
\text { Betweens" }\end{array}$} \\
\hline & No. & $\frac{\text { No. }}{48}$ & No. & $\frac{\text { No. }}{41}$ & No. & $\frac{\text { No: }}{7}$ \\
\hline Abortion & 24 & .50 & 19 & .45 & 5 & .72 \\
\hline Undecided & 5 & .11 & 4 & .10 & 1 & .14 \\
\hline $\begin{array}{c}\text { Have } \\
\text { Baby }\end{array}$ & 15 & $\cdot 32$ & 15 & $\cdot 37$ & 0 & - \\
\hline $\begin{array}{c}\text { Not } \\
\text { Available }\end{array}$ & 4 & .08 & 3 & .07 & 1 & .14 \\
\hline TotalB & 48 & & 41 & & 7 & \\
\hline
\end{tabular}


TABLE XVI

\begin{tabular}{|c|c|c|c|c|c|c|c|c|}
\hline \multirow{2}{*}{$\begin{array}{l}\text { DECISION BY AGE } \\
\text { TOTAL SAMPLE } \\
N=109\end{array}$} & \multicolumn{2}{|c|}{144189} & \multicolumn{2}{|c|}{$19 \overline{2} z 9$} & \multicolumn{2}{|c|}{$2\{1\} 2\}$} & \multicolumn{2}{|c|}{$23-49$} \\
\hline & No. & $\frac{\text { No. }}{48}$ & No. & $\frac{\text { No. }}{26}$ & No. & $\frac{\text { No. }}{13}$ & No. & $\frac{\text { No. }}{22}$ \\
\hline $\begin{array}{r}\text { Therapeutic } \\
\text { Abortion }\end{array}$ & 24 & .50 & 16 & .61 & 10 & .77 & 16 & .7 .3 \\
\hline $\begin{array}{l}\text { Marriage and } \\
\text { Have Baby }\end{array}$ & 7 & .15 & 5 & .19 & 2 & .15 & 3 & .14 \\
\hline $\begin{array}{l}\text { Have and keep } \\
\text { Baby--Single }\end{array}$ & 5 & .10 & 1 & .04 & 0 & - & 0 & - \\
\hline $\begin{array}{l}\text { Have Baby } \\
\text { Decide Later }\end{array}$ & 3 & .06 & 0 & - & 0 & - & 0 & - \\
\hline Undecided & 5 & .10 & 1 & .04 & 1 & .08 & 0 & - \\
\hline Unavailable & 4 & .08 & 3 & .16 & 0 & - & 3 & .14 \\
\hline
\end{tabular}

TABLE XVII

\begin{tabular}{|c|c|c|c|c|}
\cline { 2 - 5 } \begin{tabular}{|l} 
ABORTION PERCENT \\
\cline { 2 - 5 }
\end{tabular} & $14-18$ & $19-20$ & $21-22$ & $23-40$ \\
\hline $\begin{array}{c}\% \text { of Abortion } \\
\text { in age group }\end{array}$ & $54.5 \%$ & $70.1 \%$ & $76.9 \%$ & $84.1 \%$ \\
\hline
\end{tabular}

MARRIAGE AND \begin{tabular}{c|c|c|c|c|}
\cline { 2 - 5 } \begin{tabular}{c} 
HAVE BABY \\
\cline { 2 - 5 }
\end{tabular} & $14-18$ & $19-20$ & $21-22$ & $23-40$ \\
\hline $\begin{array}{c}\text { Already } \\
\text { Married }\end{array}$ & 3 & 3 & 1 & 3 \\
\hline $\begin{array}{c}\text { WIII } \\
\text { Marry }\end{array}$ & 4 & 2 & 1 & - \\
\hline
\end{tabular}

TABLE XIX

DECISION BY PREVIOUS ABORTION OR RELEASE

\begin{tabular}{|c|c|c|c|}
\cline { 2 - 4 } & $\begin{array}{c}\text { Therapeutic } \\
\text { Abortion }\end{array}$ & $\begin{array}{c}\text { Marriage } \\
\text { with baby }\end{array}$ & $\begin{array}{c}\text { Have baby } \\
\text { decide late }\end{array}$ \\
\hline $\begin{array}{c}\text { Previous } \\
\text { Abortion }\end{array}$ & 4 & 2 & - \\
\hline $\begin{array}{c}\text { Previous } \\
\text { Release }\end{array}$ & 4 & - & 1 \\
\hline
\end{tabular}


TABLE XX

DECISION BY MARRIAGE

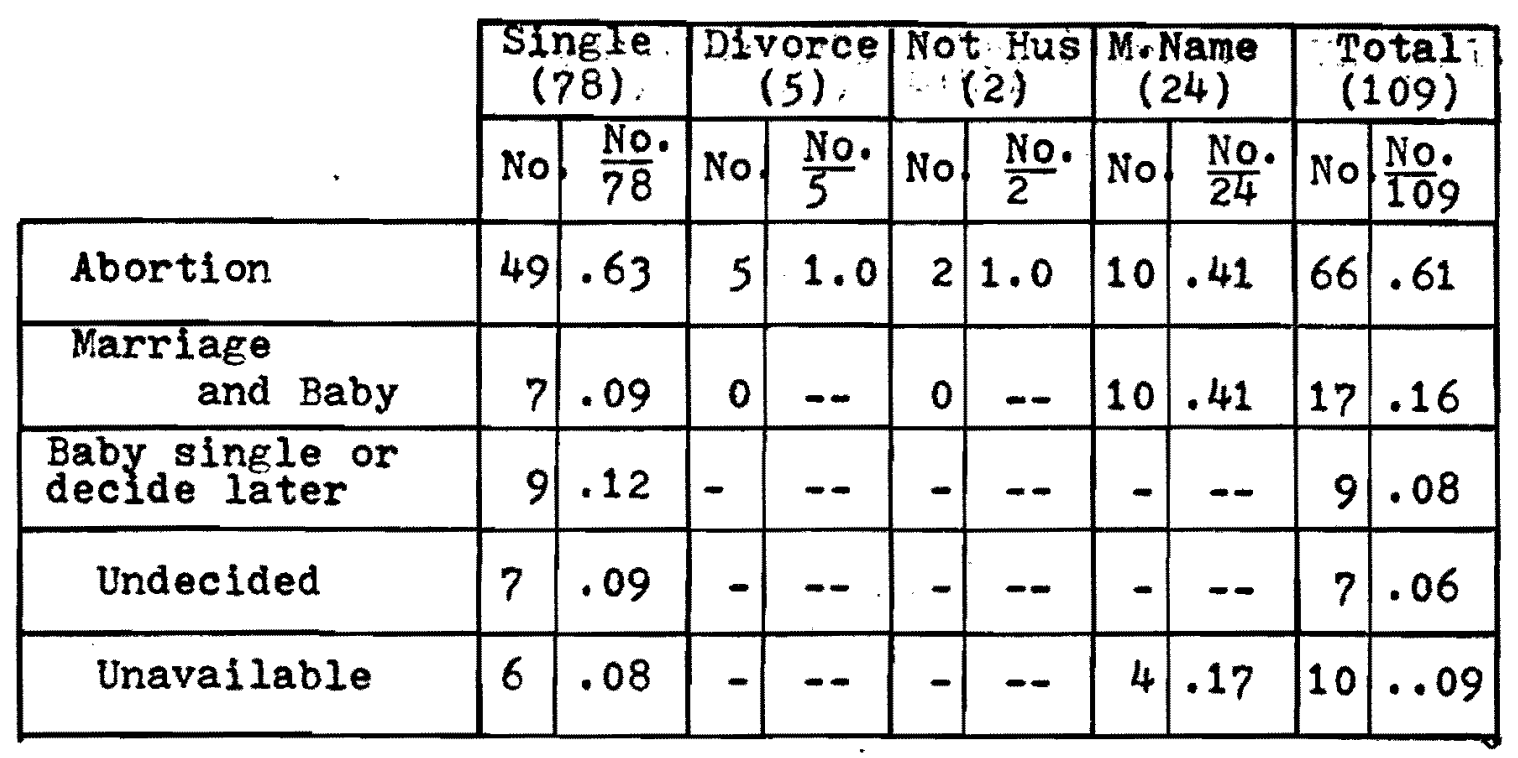

TABLE XXI

\begin{tabular}{|c|c|c|c|c|c|c|c|c|c|c|}
\hline \multirow{2}{*}{$\begin{array}{c}\text { DECISION BY MAR. } \\
\text { UNAVAILABLE } \\
\text { OMITTED }\end{array}$} & \multicolumn{2}{|c|}{$\begin{array}{c}\text { Single } \\
(72)\end{array}$} & \multicolumn{2}{|c|}{$\begin{array}{c}\text { Divorce } \\
(5)\end{array}$} & \multicolumn{2}{|c|}{$\begin{array}{c}\text { Not Hus } \\
\text { (2) }\end{array}$} & \multicolumn{2}{|c|}{ M. Name } & \multicolumn{2}{|c|}{$\begin{array}{l}\text { Total } \\
(99)\end{array}$} \\
\hline & No & $\frac{10}{72}$ & No & $\frac{\text { No. }}{5}$ & No & $\frac{\text { No. }}{2}$ & No & $\frac{\text { No. }}{20}$ & No & $\frac{\text { No. }}{99}$ \\
\hline Abortion & 49 & .68 & 5 & 1.0 & 2 & 1.0 & 10 & .50 & 66 & .67 \\
\hline $\begin{array}{l}\text { Marriage } \\
\text { and Baby }\end{array}$ & 7 & .10 & - & -- & - & -- & 10 & .50 & 17 & .17 \\
\hline $\begin{array}{l}\text { Baby single or } \\
\text { decide later }\end{array}$ & 9 & .13 & - & -- & - & -- & - & -- & 9 & .09 \\
\hline Undeci & 7 & .10 & - & - & - & - & - & -- & 7 & .07 \\
\hline
\end{tabular}

TABLE XXII

\begin{tabular}{|c|c|c|c|c|c|c|}
\cline { 2 - 7 } NO PUTURE CHIIDREN & \multicolumn{2}{c|}{ Abortion } & \multicolumn{2}{|c|}{ Have baby } & \multicolumn{2}{c|}{$\begin{array}{c}\text { Not } \\
\text { Available }\end{array}$} \\
\hline N=15 Positive Resp. & 11 & $73.3 \%$ & 1 & $6.7 \%$ & 3 & $20.0 \%$ \\
\hline N=12 $\begin{array}{c}\text { Unavailable } \\
\text { Omitted }\end{array}$ & 11 & $92.5 \%$ & 1 & $7.5 \%$ & & \\
\hline
\end{tabular}


TABLE XXIII

DECISION BY NO. OF CHILDREN WITH MOTHER

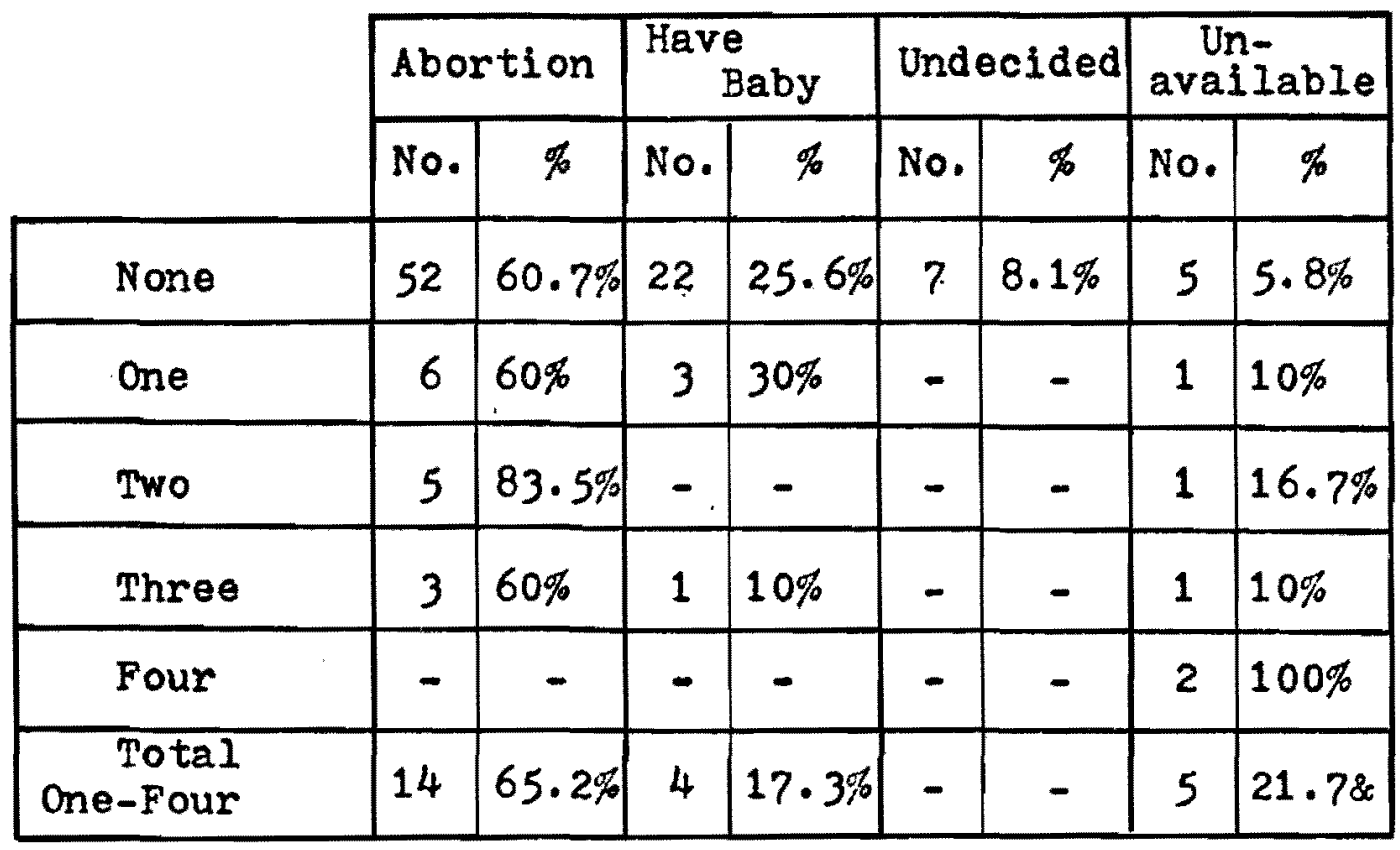

TABLE XXIV

DECISION EY NO. OF CHILDREN WITH MOTHER

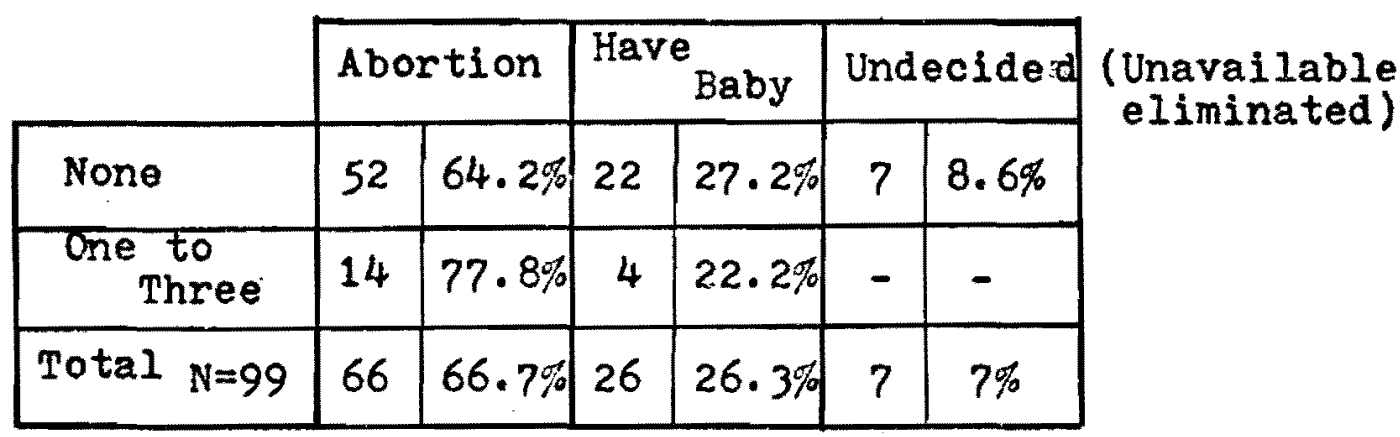

TABLE XXV

DECISION BY CONTRACEPTIVE FAILURE REIIABLE METHOD

\begin{tabular}{|c|c|c|c|c|c|c|}
\cline { 2 - 7 } \multicolumn{1}{c|}{} & \multicolumn{2}{|c|}{ Abortion } & \multicolumn{2}{|c|}{ Baby } & \multicolumn{2}{c|}{ Undecided } \\
\hline $\begin{array}{c}\text { Reliable Method } \\
(16) \text { Falures }\end{array}$ & 13 & $81.3 \%$ & 3 & $18.7 \%$ & & - \\
\hline Other (83) & 53 & $63.9 \%$ & 23 & $27.7 \%$ & 1 & $8.2 \%$ \\
\hline
\end{tabular}




\section{TABLE XXVI}

DO YOU WANT FUTURE CHILDREN?

\begin{tabular}{|l|c|c|l|l|}
\cline { 2 - 5 } \multicolumn{1}{c|}{$N$ No109 } & \%of N & Mean Age & Age Range \\
\hline Not asked & 26 & $23.9 \%$ & $18.6 \mathrm{yrs}$. & 14 to 24 \\
\hline Yes* & 62 & $57.8 \%$ & $18.7 \mathrm{yrs}$. & 14 to 27 \\
\hline Maybe & 5 & $46 \%$ & $22.7 \mathrm{yrs}$. & 18 to 31 \\
\hline No** & 15 & $13.8 \%$ & $27.4 \mathrm{yrs}$. & 16 to 40 \\
\hline Total Sample & 109 & $100 \%$ & $20.7 \mathrm{yrs}$. & 14 to 40 \\
\hline
\end{tabular}

* Eliminating 6 where the plan in not recorded 35 out of $57(61.4 \%)$ elected abortion of those answering Yes.

* The "No" group included a 16.yr. old with a severe genetic disease. If she is eliminated Mean age $=27.9$ and Age Range+ 19-40.

Eleven out of fifteen "Nos" had children at home.

TABLE XXVII

NO FUTURE CHILDREN EVER BY NUMBER OF CHILDREN

\begin{tabular}{|c|c|c|c|}
\hline \multicolumn{2}{|r|}{$N=15$} & No. & Age of Mother \\
\hline 0 & Children & 4 & $16,25,28,29$ \\
\hline 1 & Child & 2 & 20,24 \\
\hline 2 & Children & 4 & $19,31,35,40$ \\
\hline 3 & Children & 4 & $19,26.33$ \\
\hline & Children & 1 & 29 \\
\hline
\end{tabular}


TABLE XXVIII

REFERRAL BY DECISION

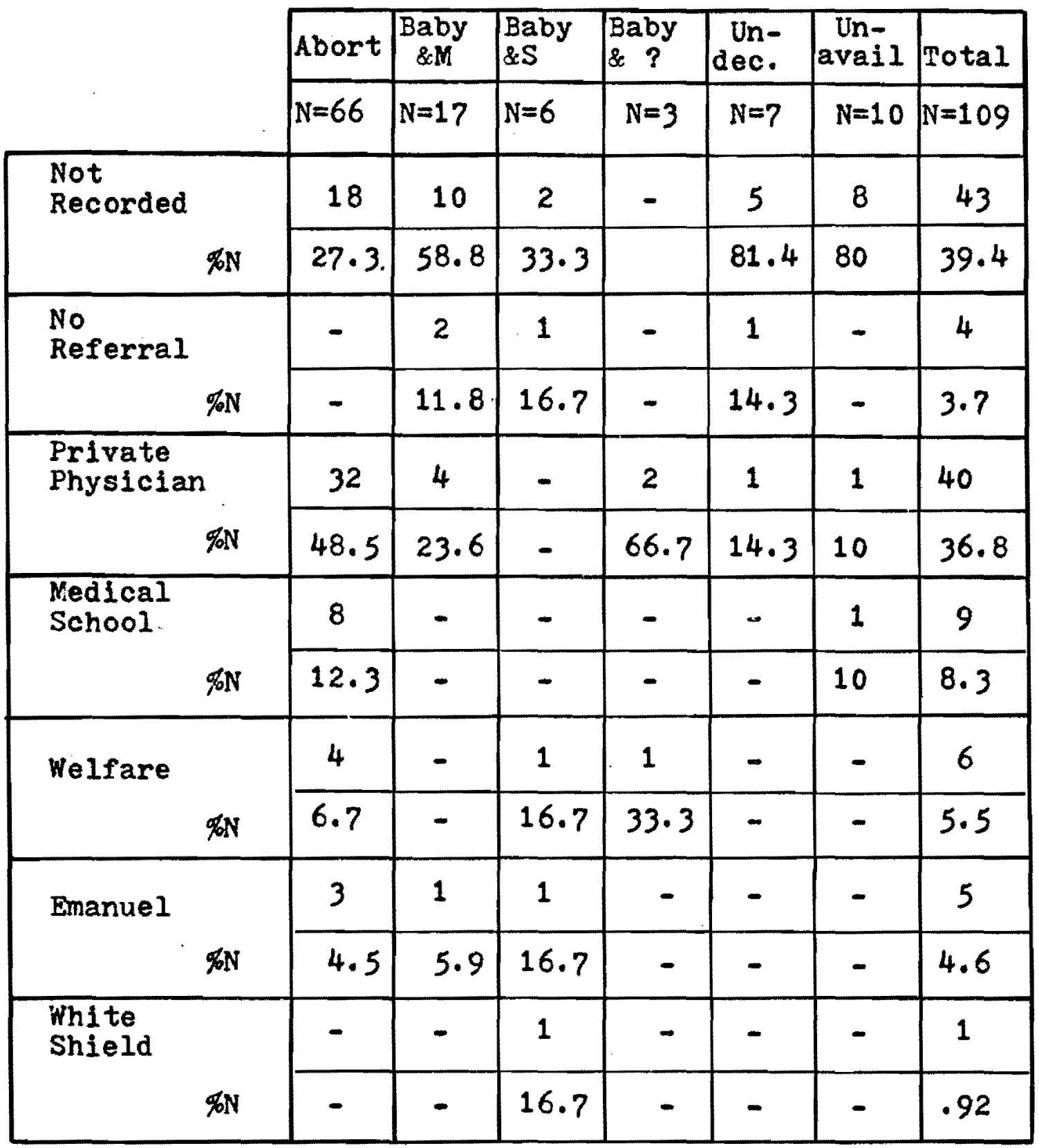

Only primary referral tabulated.

Some welfare also included in Private Phys. for Abort.

There were a few mental health referrals (not tabulated) 
TABLE XXIX

ESSENTIAL DATA OMITTED BY CALENDAR QUARTER

\begin{tabular}{|c|c|c|c|c|}
\cline { 2 - 5 } \multicolumn{1}{c|}{ N=109 } & $\begin{array}{c}\text { Jan.- } \\
\text { March }\end{array}$ & $\begin{array}{c}\text { April- } \\
\text { June }\end{array}$ & $\begin{array}{c}\text { July- } \\
\text { Sept. }\end{array}$ & $\begin{array}{c}\text { Oct.- } \\
\text { Dec. }\end{array}$ \\
\hline Number of Cases & 28 & 18 & 25 & 38 \\
\hline Plan not Recorded & 4 & 2 & 1 & 3 \\
\hline $\begin{array}{c}\text { Referral not } \\
\text { Recorded }\end{array}$ & 8 & 9 & 9 & 17 \\
\hline $\begin{array}{c}\text { No Information } \\
\text { Contraception } \\
\text { rei Conception }\end{array}$ & 9 & 5 & 12 & 12 \\
\hline $\begin{array}{c}\text { Gestation } \\
\text { not Recorded }\end{array}$ & 3 & 1 & 2 & 2 \\
\hline $\begin{array}{c}\text { Total of all } \\
\text { Omissions }\end{array}$ & 24 & 17 & 24 & 34 \\
\hline $\begin{array}{c}\text { Number of cases } \\
\text { with one or more } \\
\text { Omissions (68) }\end{array}$ & 16 & 14 & 15 & 23 \\
\hline $\begin{array}{c}\text { Percent cases } \\
\text { one or more } \\
\text { Omissions 62.4\% }\end{array}$ & $57.1 \%$ & $77.7 \%$ & $60 \%$ & $60.5 \%$ \\
\hline $\begin{array}{c}\text { Total Omissions } \\
\text { by no. of cases } \\
\text {-908 }\end{array}$ & .857 & .944 & .96 & .895 \\
\hline
\end{tabular}

* Six out of eight Gestation Omissions are on the 16 old patients seen in the regular (non-PCG) clinic. 